\title{
FORGING AN AUSTRALASIAN REGION: \\ TRANS-TASMAN INTEGRATION AND INTERREGIONALISM IN THE ASIA-PACIFIC
}

\author{
By \\ Matthew Adrian Castle
}

\begin{abstract}
A thesis
Submitted to the Victoria University of Wellington in fulfilment of the requirements for the degree of

Master of Arts

in International Relations
\end{abstract}

School of History, Philosophy, Political Science \& International Relations Victoria University of Wellington 


\section{Abstract}

Most commentators view the Australia-New Zealand Closer Economic Relations (CER) agreement as a remarkable example of bilateral integration. CER is not usually regarded, however, as a platform for Australia and New Zealand to jointly engage with third parties. Yet, more than a decade of CER-ASEAN relations culminated, in 2010, in a Free Trade Agreement (the ASEAN-Australia-New Zealand FTA, AANZFTA) between the two regions. This suggests that intra-regional trans-Tasman integration might "spill over" into external cooperation with third parties. Close cooperation and joint approaches have not, however, eventuated in other cases. Australia and New Zealand applied separately to join the interregional Asia-Europe Meeting (ASEM) forum in 2008 and 2009 , indicating that their ability to act as a region is not consistent across policy or issue areas. This is an intriguing empirical puzzle, given that most observers of interregionalism elsewhere understand the ability of regions to act in international relations ('actorness') as a general, rather than variable, characteristic. Why, then, did Australia and New Zealand negotiate as a single entity with ASEAN on an FTA, but did not coordinate their approach in the ASEM case?

This thesis argues that the process of trans-Tasman integration has produced a set of issue-specific institutions, which present Australian and New Zealand policy makers with a ready-made framework for cooperation with third parties in some, but not all, issue areas. Once these institutions were established, it proved a relatively simple step to extend the scope of their operation beyond the trans-Tasman level. This suggests that in the trans-Tasman case, 'actorness', understood as the basis on which regions can engage in international relations, may be issue-specific rather than generalised.

This thesis makes its case by critically analysing the emergence and evolution of CERASEAN relations and by documenting Australia and New Zealand's separate applications to join ASEM. It draws on extensive archival research and interviews with key actors and decision makers.

The thesis adds to the nascent field of interregionalism by offering a new empirical case in which to test and develop theories. It makes a contribution to our understanding of the way institutions shape the scope for regions to "act" in international relations. More broadly, this study provides insights into the relationship between institutional design, individual actors and policy outcomes. 


\section{Acknowledgements}

My first thanks go to my primary research supervisor, Dr John Leslie. John, I am grateful for your time, thoughts and energy. You have made me a more disciplined researcher and writer and, I hope, a more incisive one. Thanks also to my secondary supervisor, $\mathrm{Dr}$ David Capie. David, you provided me with much appreciated encouragement and advice - even from the other side of the world.

My appreciation also goes to other staff within the Political Science and International Relations programme at VUW. Thanks in particular to Dr Fiona Barker for employment and support during my MA tenure.

My gratitude goes to everyone at the Asia-Europe Foundation in Singapore. To Ambassador Dominique Girard and to Leonie Nagarajan, thank you for your willingness to assist me with my research. To my interview subjects in Singapore and New Zealand on and off the record - thank you for your insights and frankness.

My thanks and appreciation go to Victoria University of Wellington and to the European Union Centres Network (EUCN) for funding and conference opportunities. This financial assistance allowed me to fully devote myself to my studies, and also enabled me to pursue research opportunities that would not otherwise have been possible. This included research undertaken during my six months in Singapore.

To my friends who have had a hand in reading or discussing parts of my work, your help has been invaluable. Thank you for being a sounding board for ideas and keeping me entertained with comments. Andy Horwood, you in particular are a trooper.

My gratitude and love as always go to my family. To my parents Ben and Bridget Castle and to my sister Jessica, your support, love and laughter helped to get me through the hardest months and to enjoy the best. You taught me balance and gave me strength. Thank you.

To Lucy King go my final and deepest thanks, with my love. I have put you through far more than you deserve this year, including disappearing overseas for half of it. Despite this, your support has been constant. Thank you for food, laughter, love and dedicated editing. You are my harshest critic and most faithful supporter and this wouldn't have been possible without you.

The responsibility for the end result is wholly mine. 


\section{Table of Contents}

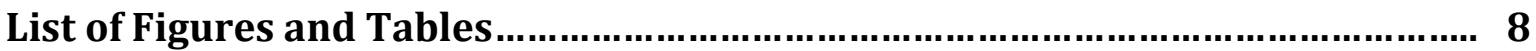

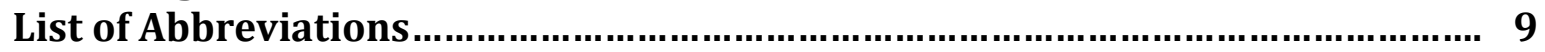

$1.0 \quad$ Introduction: Research Problem........................................................ 11

$1.1 \quad$ Research Questions and Approach....................................................... 12

1.2 Contending Hypotheses..................................................................... 12

$1.3 \quad$ Research Justification.......................................................................... 14

$1.4 \quad$ Chapter Outline .............................................................................. 15

$\begin{array}{lll}2.0 & \text { Review of the Literature } & 18\end{array}$

2.1 Regional Integration as a Dependent Variable............................................. 20

2.2 Interregionalism in International Relations .............................................. 24

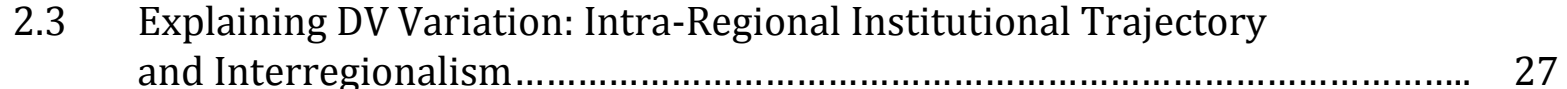

2.4 Research Methodology, Case Selection and Limitations.................................. 29

$2.5 \quad$ Conclusion....................................................................................... 31

3.0 Australia and New Zealand: Integration and Economic Opening in Historical Perspective................. 32

3.1 Trans-Tasman Integration: International and Intra-Regional Drivers............ 34

3.2 Australia, New Zealand and ASEAN - historical policy convergence............... 46

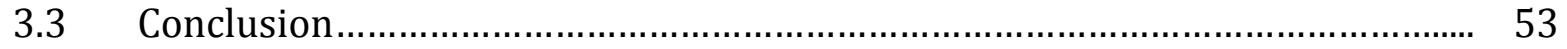

4.0 Case I: The ASEAN-Australia-New Zealand Free Trade Agreement......... 55

4.1 AANZFTA: From Proposal to Signatures..................................................... 57

4.2 Issue Specificity and the Adaptability of Trans-Tasman Institutions............... 64

4.3 Deepening and Broadening Interregional Integration.................................... 71

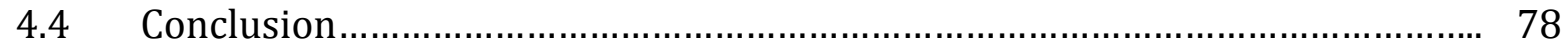

5.0 The Asia-Europe Meeting (ASEM) ……............................................. 81

5.1 Background: ASEM and Contending Visions for Asian Regionalism................ 83

5.2 "Ambition" and a Seat at the Table: Australia in ASEM.................................. 90

5.3 Hedging the Bets: New Zealand in ASEM.................................................... 93

5.4 Understanding Convergence and Divergence.............................................. 98

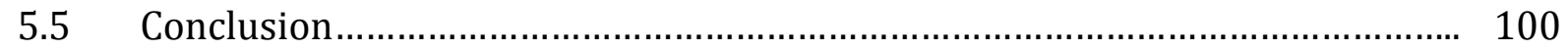

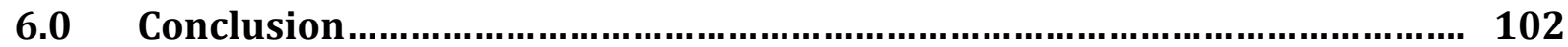

6.1 Summary of Main Findings .......................................................................... 103

6.2 Implications of the Research Findings: Looking Forward............................... 108

$6.3 \quad$ A Future Research Agenda...................................................................... 112

6.4 Final Conclusions.................................................................................. 115

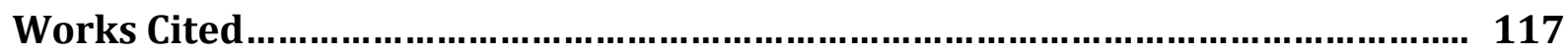




\section{List of Figures}

Figure 1: $\quad$ Australia's Merchandise Exports to the United Kingdom and New Zealand as Percentage of Total Australian Merchandise Exports, 1900-2000......... 35

Figure 2: $\quad$ New Zealand's Merchandise Exports to the United Kingdom and Australia as Percentage of Total New Zealand Merchandise Exports, 1900-2000...... 35

Figure 3: $\quad$ Figure 3: The ASEM Institutional Structure .......................................... 86 


\section{Acronyms and Abbreviations}

\begin{tabular}{|c|c|}
\hline AANZFTA & ASEAN-Australia-New Zealand Free Trade Agreement \\
\hline AANZTNC & ASEAN-Australia-New Zealand Trade Negotiating Committee \\
\hline ACCSQ & ASEAN Consultative Committee on Standards and Quality \\
\hline ACBC & ASEAN-CER Business Council \\
\hline AEC & ASEAN Economic Council \\
\hline AECF & Asia-Europe Cooperation Framework \\
\hline AEBF & Asia-Europe Business Forum \\
\hline AEM & ASEAN Economic Ministers \\
\hline AFTA & ASEAN Free Trade Agreement/Area \\
\hline ANZCCSQ & $\begin{array}{l}\text { (Proposed) Australia-New Zealand Consultative Committee on Standards } \\
\text { and Quality }\end{array}$ \\
\hline ANZCERTA & Australia-New Zealand Closer Economic Relations Trade Agreement \\
\hline ANZFSA & Australia-New Zealand Food Standards Authority \\
\hline APEC & Asia-Pacific Economic Cooperation \\
\hline $\mathrm{ARF}$ & ASEAN Regional Forum \\
\hline ASAQ & Agreement on Standards, Accreditation and Quality \\
\hline ASEAN & Association of South East Asian Nations \\
\hline ASEAN+3 & ASEAN, China, Japan, South Korea \\
\hline ASEF & Asia-Europe Foundation \\
\hline ASEM & Asia-Europe Meeting \\
\hline CEP & (ASEAN-CER) Closer Economic Partnership \\
\hline CER & Closer Economic Relations (for ANZCERTA) \\
\hline COAG & Council of Australian Governments \\
\hline CSIRO & Commonwealth Scientific and Industrial Research Organisation \\
\hline CRI & Crown Research Institute \\
\hline DFAT & (Australian) Department of Foreign Affairs and Trade \\
\hline DIST & Department of Industry, Science and Technology \\
\hline EAEC & East Asian Economic Caucus \\
\hline EAEG & East Asian Economic Grouping \\
\hline EAS & East Asia Summit \\
\hline EC & European Commission \\
\hline EEC & European Economic Community \\
\hline EPA & Environmental Protection Agency \\
\hline EU & European Union \\
\hline FMM & (ASEM) Foreign Ministers Meeting \\
\hline FSANZ & Food Standards Australia-New Zealand \\
\hline FTA & Free Trade Agreement \\
\hline GATT & General Agreement on Tariffs and Trade \\
\hline GSPs & General Scheme of Preferences \\
\hline
\end{tabular}


IFRI Institut Français des Relations Internationales

(French Institute of International Relations)

JAS-ANZ Joint Accreditation System of Australia and New Zealand

JTMG (Standards Australia and Standards New Zealand) Joint Technical Management Group

MFAT (New Zealand) Ministry of Foreign Affairs and Trade

MoU Memorandum of Understanding

MSL Measurement Standards Laboratory

NSC (Australian) National Standards Commission

NAFTA New Zealand-Australia Free Trade Agreement (usually); or

North American Free Trade Agreement

NATA (Australian) National Association of Testing Authorities

NTA New Trans-Atlantic Agenda

OPEC Oil and Petroleum Exporting Countries

RTA Regional Trade Agreement

SA Standards Australia

SEM (Australia-New Zealand) Single Economic Market

SNZ Standards New Zealand

SEOM (ASEAN) Senior Economic Officials Meeting

SOM (ASEM) Senior Officials Meeting

SPC Special Premiers Conference

TMU Trade Measurement Unit

TPP/TPPA Trans-Pacific Partnership (Agreement)

TTMRA Trans-Tasman Mutual Recognition Arrangement

UK United Kingdom

WTO World Trade Organisation 


\section{One}

\section{Introduction}

The November 2004 launch of Free Trade Agreement negotiations between Australia, New Zealand and ASEAN was a milestone in the Australia-New Zealand relationship. The agreement is the first that New Zealand and Australia have jointly negotiated with a third party, suggesting spillover from internal trans-Tasman policy cooperation to external cooperation. Such trans-Tasman cooperation evinced by the ASEAN-AustraliaNew Zealand Free Trade Agreement (AANZFTA) negotiations has not, thus far, been replicated in other cases however. As AANZFTA was being concluded in 2008, Australian Prime Minister Kevin Rudd announced Australia's unilateral decision to seek an application to the Asia-Europe Meeting (ASEM) process. New Zealand followed suit in 2009 with its own, independent application.

While there is no reason to assume automatic trans-Tasman cooperation on an issue like ASEM membership, variance in Australia-New Zealand cooperation between the AANZFTA and ASEM cases raises an empirical puzzle. It suggests that spillover from internal to external trans-Tasman cooperation is not a generalised phenomenon, but rather takes place only in certain circumstances. This is intriguing, given that most observers of region-to-region relations elsewhere suggest that the capacity of regions to act in international relations (known as "actorness") is a general, rather than variable characteristic. Why enabled Australia and New Zealand to cooperate with ASEAN, but not in the ASEM case? 


\subsection{Research Questions and Approach}

This thesis elucidates this puzzle. With particular reference to the AANZFTA and ASEM cases it asks, how and why can trans-Tasman cooperation in internal policy areas spill over into external cooperation in foreign or trade policy?

There are a number of secondary questions that follow on from this main research question:

- Who (which actors) drove spillover in one case, but not in the other - Australian and New Zealand governments, or actors within supranational trans-Tasman institutions?

- Are certain areas seen as 'natural' grounds for cooperation?

- To what extent does external trans-Tasman cooperation depend on existing trans-Tasman integration, and to what extent is it a product of changes and forces in the international environment?

\subsection{Contending Hypotheses}

This project's research puzzle relates to two connected areas of study - regional integration and interregionalism. Both fields have developed causal hypotheses that relate to this project's research focus. Explanations for regional integration point to drivers at the regional or national level, as well as in the international environment. A division exists in this literature between interpretations that stress the centrality of state actors in advancing and limiting integration, and explanations that hold - as does this thesis - that (supranational) institutions can alter actor preferences, resulting in a more dynamic process of integration driven by the "spillover" from cooperation in one sector to cooperation in others. Supranational institutions are central to these processes, 
but recognition of their existence (in different forms) beyond Europe, including between Australia and New Zealand, is lacking in this literature.

At the international level, observed drivers of integration include the failure of multilateralism, systematic shocks to the international economy, the "contagious" nature of regional trading agreements, and the power of normative diffusion. These hypotheses provide insight into some of the external motivations for trans-Tasman policy cooperation but fall short of a complete explanation as they do not adequately explain internal variance in spillover.

Drawing on theory developed by observers of European external relations, scholarship on interregionalism on the other hand rests largely on the assumption that regions require a measure of "actorness" to engage in international relations. This concept usefully underscores the importance of paying attention to specific regional capacities in assessing the ability of states to act as regions in international relations. As it is applied in interregionalism, actorness is, however, a Euro-centric concept in that it is proposed as a general quality of the region. This is consistent with the centralised and overarching institutionalisation that characterises European integration, but less useful in cases where, as between Australia and New Zealand, integration has resulted in decentralised institutions.

This project contends that spillover from intra-regional to external trans-Tasman cooperation is enabled by existing trans-Tasman regional institutions. The history of trans-Tasman economic integration has resulted in decentralised, issue-specific institutions rather than a single over-arching institutional framework. Although different to those of European integration, these institutions have some supranational qualities, and have resulted in a process of integration that has occurred in depth in 
issue-areas where trans-Tasman institutions have been concentrated. The research presented in this thesis suggests moreover that state actors are not the only drivers of integration. Actors from within the trans-Tasman institutional environment have also contributed to integration. Trans-Tasman institutions provide a framework for the strategic pursuit of Australian and New Zealand goals. They also shape the preferences, self-perceptions and world-view of actors within them and who function in their issue areas. This encourages trans-Tasman actors to evaluate events, problems and possibilities from a trans-Tasman rather than national perspective. In terms of a basis on which Australia and New Zealand might jointly engage in interregionalism or in international relations more generally, this thesis suggests that actorness should be conceived in the trans-Tasman case as an issue-specific variable, rather than a general quality of the region.

\subsection{Research Justification}

This research fills an important gap in the literature on regional integration and interregionalism by re-evaluating the foundation on which states within regions jointly coordinate in international relations. It also adds a case that has hitherto received limited attention in this literature. More importantly, this project conducts valuable and timely research on a phenomenon that is of singular importance to Australia and New Zealand. An understanding of how and why new forms of cooperation emerge between the two countries will only become more valuable as both countries increasingly seek to engage with an economically dynamic Asia-Pacific. 


\subsection{Chapter Outline}

The remainder of this thesis proceeds in the following manner. Chapter Two situates the current study in the literature on regional integration and interregionalism. It critically evaluates existing hypotheses for regional policy cooperation and interregional relations. It then presents this project's contending hypothesis, and discusses the research methodology and limitations of this project.

Chapter Three provides the empirical background for the study. It firstly presents a brief history of trans-Tasman integration. Early efforts at integration overcame the competition and occasional animosity between Australia and New Zealand that had previously existed, motivated by the potentially diversionary impact of European integration and by changing domestic interests. A failure to achieve satisfactory multilateral liberalisation of agricultural products and frustration with the existing trade relationship led to CER's introduction. This first section demonstrates the importance of existing trans-Tasman institutions in facilitating later integration by providing available institutional structures and by encouraging officials in Australia and New Zealand to jointly cooperate through socialisation. The second part of Chapter Three describes early Australia-ASEAN and New Zealand-ASEAN relations. Policy convergence between Australia and New Zealand was frequent, but no formal cooperation took place despite some evidence that this may have served mutual interests. A major factor for this seems to have been the lack of an adequate institutional framework to support such cooperation.

Chapters Four and Five test the project's hypothesis. Building on the empirical foundations provided by the latter section of Chapter Three, Chapter Four examines the history and negotiations of the ASEAN Australia-New Zealand Free Trade Agreement 
(AAZNFTA). Drawing on archival evidence, the chapter traces the development of the CER-ASEAN relationship during the 1990s, demonstrating the central role of transTasman institutions in advancing these relations. These institutions provided a means of achieving joint trans-Tasman goals with ASEAN, but also became active drivers of the relationship on a region-to-region basis. A dense inter-institutional interregional network developed between CER and ASEAN in the 1990s, laying the foundations for the negotiations of the AANZFTA from 2005 to 2008.

Chapter Five examines Australia and New Zealand's membership applications to the Asia-Europe Meeting (ASEM). It traces the two countries' interest in the process before comparatively examining their independent membership applications. It discusses why Australia and New Zealand did not cooperate on their application. It suggests that the politicised ASEM summit format, the strategic implications of a joint application and a lack of available trans-Tasman institutions meant that the political costs of cooperation between Australia and New Zealand on ASEM would simply have been too high. ASEM reflects a normal level of divergence between Australia and New Zealand in international relations; this helps to illustrate the convergence of factors that enabled Australia-New Zealand cooperation with ASEAN.

Chapter Six concludes. In making its argument, this research makes a valuable addition to our understanding of the dynamics of trans-Tasman integration, while also contributing to the broader literature on regionalism and interregionalism. Australia and New Zealand's cooperation on AANZFTA is so far the sole example of Australia and New Zealand entering joint negotiations with a third party in international relations. Spillover from internal to external cooperation in this case relied on the availability of issue-relevant institutions. In the ASEM case, after separate application processes 
Australia and New Zealand now find themselves cooperating closely in a newly-devised membership category. Collaboration within this institution may ironically provide a template for future trans-Tasman cooperation in other regional fora. The thesis closes with some implications for the shape of trans-Tasman cooperation in the coming decades. Australia and New Zealand's future lies with Asia, and AANZFTA provides a glimpse of how this future may be jointly navigated. 


\section{Two}

\section{Review of the Literature}

Australia and New Zealand chose to jointly negotiate on AANZFTA, but did not cooperate on an application to ASEM. What explains this empirical puzzle? This thesis asks how and why trans-Tasman cooperation in internal (intra-regional) policy areas can develop into external cooperation in foreign or trade policy. What encourages spillover in one case, but not in another? This thesis posits that the drivers of regional integration may be internal or external, but that variance in policy spillover from the regional to external level is explained by the particular trans-Tasman institutional framework. This claim contends with existing hypotheses about the forces driving regional integration and the basis on which region-to-region cooperation takes place, which have been developed in scholarship on regional integration and interregionalism. This chapter situates the current study within this wider body of literature.

It proceeds in three main sections. Section 2.1 introduces a number of competing explanations for the drivers of regional integration. These relate to internal (regional and domestic) as well as external (international) factors. Scholarship on the internal drivers of integration has historically distinguished between state and non-state actors. In the European context, the corollary of this distinction has been a division between state-centric analyses in which supranational institutions play a passive role and neofunctional or multi-level analyses that accord a more active role to these institutions. Recognition that supranational institutions exist beyond the EU has been lacking. Scholarship focussing on dynamics in the international environment cites, for instance, defensive or offensive economic interests, or cognitive factors. The effects of all of these 
forces on trans-Tasman integration are evident, but they do not explain variance in Australia-New Zealand cooperation in the two cases at hand.

Section 2.2 explores existing scholarship on interregionalism. By asking how transTasman integration affects Australia and New Zealand's involvement in interregional relations, the current project approaches this relationship from the opposite side of much of the literature on interregionalism, which has tended to examine how interregionalism can affect regional integration. This project is complementary rather than oppositional to this body of literature however, as it provides an empirical case that has hitherto been overlooked in this field of academic inquiry.

Section 2.3 explicates the central claim of this thesis. It contends that although the motivations for trans-Tasman cooperation may be internally or externally derived, variation in spillover of trans-Tasman policy cooperation from internal to external policy areas is the result of the de-centralised and issue-specific nature of the transTasman institutional framework. Institutions have provided a framework for transTasman policy cooperation in particular issue-areas and not in others. These institutions have also played a more active role in determining the scope of spillover by shifting the preferences of trans-Tasman actors and advancing their own interests in the CERASEAN relationship.

Section 2.4 discusses the case selection and methodology adopted in this project, as well as the limitations of the project. 


\subsection{Regional Integration as a Dependent Variable}

\section{Internal factors affecting regional integration}

Early theorists of regional integration drew from the most prominent case available Europe. This thesis makes no effort to resolve debates pertaining to European integration and will not rehearse conflicting arguments at any length here, ${ }^{1}$ but an important division within this literature comes to bear on the current project. Observers of European integration have historically been split into those who see it as a statedriven process and those who stress the role of non-state actors in advancing integration. This debate plays out in the trans-Tasman case.

Intergovernmental or liberal intergovernmental perspectives suggest that regional integration is the outcome of bargaining by state actors within passive regional institutions (Moravcsik 1991, 1993, 1998; Schimmelfennig 2004). Such an approach is (implicitly) taken by many observers of trans-Tasman integration. Commentators have for instance noted the importance of individual politicians at particular points during integration - as during the successful 1988 Review of CER (Scollay, Findlay, and Kaufmann 2011, 26). Others have observed that trans-Tasman integration has advanced as a function of the emphasis placed on it by different domestic governments (Lloyd 1995; Eichbaum and Gerritsen 1993), or that there is economic convergence and political divergence as a result of conflicting political agendas in Australia and New Zealand (Patman 2001; Goff 2001). Such analyses pay relatively scant attention to the role of the trans-Tasman institutional environment in shaping integration. Leslie and Elijah (2011) on the other hand argue that although it is state actors who drive trans-

\footnotetext{
${ }^{1}$ For an overview of European theories see the collection edited by Wiener and Diez (2004).
} 
Tasman integration, it is within the structured constraints established by available institutions.

Contending perspectives emphasise the role played by non-state actors. Various scholars have for instance observed the importance of business interests in Europe and North America in pushing for greater economic integration through lobbying (Mattli 1999, 49-50; 77-80; Cowles 1995; Bhagwati 1999; Chase 2003). In the trans-Tasman case, the role of these particular non-state actors has been less evident (Leslie and Elijah 2011). As neo-functionalists have argued however, non-state actors who play a determinative role in regional integration also include members of regional (supranational) institutions. These actors capitalise on the "spill-overs" and "unintended consequences" that result when authority is pooled at the supranational level (Schmitter 2004). Multi-level governance perspectives (Hooghe and Marks 2001; Marks, Hooghe, and Blank 1996) similarly accord a role to non-state actors. Such analyses suggest that different levels of regulatory authority are 'nested' within one another. The distinction between national and international actors and between the public and private sectors is thereby broken down. This approach is also useful in understanding CER-ASEAN relations, in which links were established and have been maintained at a number of different levels.

Theories derived from European integration therefore shed light on the processes involved in trans-Tasman integration. Recognition that supranational institutions might exist outside of the EU is, however, absent from this literature. This thesis contributes to filling this gap. As Chapter Three discusses, trans-Tasman institutions do in fact have some supranational qualities, although they are disaggregated and issue-specific rather than centralised as in the EU. 


\section{International drivers of regional integration}

Domestic and regional drivers of integration are certainly at play in the trans-Tasman case, but integration between Australia and New Zealand can also be understood with reference to forces in the international environment. One strand of political economy literature, for example, argues that regionalism is a result of the failure of economic liberalisation at the multilateral level, with regional trade agreements emerging as a more readily achievable alternative to protracted or difficult multilateral trade agreements (Krugman 1991, 1993; Bhagwati 1993). This factor is evident in the transTasman story: the exclusion of agricultural products in the Tokyo Round of GATT tariff reductions created important momentum for CER to develop, while WTO talks in Seattle in 1999 acted as an impulse to advance with AANZFTA negotiations two decades later. ${ }^{2}$

Other commentators suggest that significant political or economic events can act as a trigger for regional integration. The East Asian financial crisis of 1997-1998 encouraged regional integration as a way of sheltering regional economies from the forces of globalisation (Kawai 2005). The effects of international events are evident in the transTasman example. According to one commentator, the 1973 OPEC oil shock (along with the UK entry to the EEC) "compelled a rethink" of existing arrangements under the New Zealand Australia Free Trade Agreement (NAFTA), and led to an agreement on lower tariff rates between Australia and New Zealand (Mein Smith 2007, 164).

The apparently 'contagious' spread of regionalism has been accounted for through reference to theorised mechanisms such as the economic 'domino effect'. The diversionary impact of exclusion from regional economic arrangements encourages states to seek membership or create alternative schemes (Baldwin 1995, 1997; Mattli

\footnotetext{
${ }^{2}$ Chapters Three and Four, respectively, elaborate on these points.
} 
1999). A 'contagion' or 'domino effect' argument helps to explain trans-Tasman economic integration. The UK's 1973 entry into the EEC signalled an end to the preferential trading relationship between the UK and its former colonies. Australia and New Zealand were therefore encouraged to seek alternative trade opportunities to replace this important export market (Andre, Payton, and Mills 2003). The contagious nature of regional trade agreements contributes not only to explanations for transTasman integration, but also to the concerted efforts by Australia and New Zealand to forge formal relations with ASEAN - a potential trading partner - in the early to mid1970s.

Other international actors may encourage integration or policy convergence between states. ASEAN played an important role in the early 1990s by suggesting links between the ASEAN Free Trade Area (AFTA) and CER. This has clear parallels with the way the EU has engaged or attempted to engage with states on a regional basis (Nuttal 1990). Powerful regions like the EU or ASEAN may provide states with incentives to undertake policy reform. This may consist of, for example, trade access (Meunier and Nicolaïdis 2006) or regional membership (Mattli and Plümper 2004).

External agents such as ASEAN or the EU can also induce regional cooperation through processes of normative diffusion. The EU has acted as a norm "exporter" by encouraging regionalism in partner states and regions (Börzel and Risse 2009; Jetschke 2010). Commentators have suggested that Australia and New Zealand have, at times, been receptive to norms about particular models of regional organisation, drawing from the European experience for example in the areas of standard-setting and mutual recognition (Carroll 1995, 1999). 
The above scholarship provides insights into the international and domestic factors that drive and shape regional integration. The following section turns to scholarship on interregionalism. This scholarship helps to explain the basis on which states within regions might act together as regions in international relations.

\subsection{Interregionalism in International Relations}

What is interregionalism? One commentator (Roloff 2001, 20) describes it as "widening and deepening political, economic, societal [and ideational] interactions between international regions" (in Rüland 2010, 1271). As a phenomenon in international relations, most scholars associate the beginning of interregionalism with the launch of formal EU-ASEAN relations in 1972 (Regelsberger 1990, 5). Academic interest in interregionalism has intensified during the last two decades however, reflecting an increase in interregional relations since the end of the Cold War (Doidge 2004, 40; Doctor 2007).

Much of this recent literature has concentrated on describing possible 'functions' of interregional dialogues. They include 'balancing', 'institution building', 'rationalising', 'agenda setting' and 'collective identity formation' (Hänggi 2000, 2002; Doidge 2004; Rüland 2010; Söderbaum and Van Langenhove 2005; Doidge 2011). Some of these functions shed light on the two cases analysed in this thesis.

The 'balancing' function, for example, relates to an attempt to regulate power distribution at the global level. The efforts of economically "peripheral" countries like Australia and New Zealand to seek membership in fora such as ASEM would reflect a fear of marginalisation from economic activity within the economic "triad" of North America, Europe and Asia (Rüland 2010). This bears similarities to the 'contagion' thesis 
of regional integration as discussed in the previous section and is not without analytical merit. Alternatively and as elaborated in Chapter Five, the 2008 ASEM 7 Summit's apparent 'agenda setting' capacity prior to the inaugural G-20 Meeting in November was arguably one of the factors that encouraged Australia to apply for membership. Whether ASEM will continue to perform this sort of function remains unclear however. Understanding ASEM as a forum in which 'collective (Asian) identity formation' takes place (Gilson 2002, 2001) provides a further possible reason for Australia and New Zealand to seek membership - doing so helps to affirm that they are credible regional partners in the wider Asia-Pacific.

The aim of this thesis is not, however, to contribute to this theoretical literature through an analysis of possible 'functions' of CER-ASEAN interregionalism or of an enlarged ASEM. Rather, this project operates on the premise that it is more productive to understand when and why Australia and New Zealand might act as CER with third parties in international relations - including in an interregional context. In this sense, it is more useful to question the basis on which regions engage in interregionalism. The widely accepted explanation is that regions require a degree of 'actorness' (Sjöstedt 1977) as a pre-requisite for interregionalism. According to Rüland (2010), actorness is dependent on four variables: 'presence' and recognition in international relations; a regional identity - norms, goals and interests; the institutional capacity to make decisions; and the institutional capacity to implement those decisions (Rüland 2010).

Actorness and its above variables come with some conceptual baggage however. The concept evolved as a method of analysing European external relations (Sjöstedt 1977; Rosamond 2000; Hill 1994; Allen and Smith 1990; Bhagwati 1999; Cowles 1995), which makes it inherently Euro-centric. This is problematic in that the concept, reflected by the 
above 'variables', suggests a unitary, consolidated region - in keeping with the centralised and over-arching institutionalisation of the EU. In other words, actorness may promote an ideal-type for a 'region' that looks very much like the EU - and less like other regions. Understood as such, actorness is not a particularly helpful analytical tool to use in the trans-Tasman case. There are similarities between European and transTasman economic integration (Leslie and Elijah 2011), but there are also important differences. Unlike in the European case, trans-Tasman integration is not wholly embodied by any one agreement or set of institutions that have broad competence over many issue-areas. Rather, an issue-specific approach to integration has been adopted, where arrangements, agreements and institutions focus on governing a strictly defined policy area. The ANZCERTA is the principal umbrella agreement for integration, but certain arrangements that are central to trans-Tasman integration function in parallel with, rather than beneath this agreement. Recent liberalisation of trans-Tasman investment occurred, for example, through a "protocol" to CER (the CER Investment Protocol), but other trans-Tasman agreements are not explicitly linked to CER at all such as the Joint Accreditation System of Australia and New Zealand (JAS-ANZ, established in 1992) or the 1996 Trans-Tasman Mutual Recognition Arrangement (TTMRA). The 1973 Trans-Tasman Travel Arrangement (TTTA), which underpins the common labour market by regulating the movement of people, pre-dates CER by an entire decade.

This thesis accordingly suggests that actorness in the trans-Tasman context should be understood as quality of the region that is issue-specific rather than general. The ability of Australia and New Zealand to 'act' together varies across policy areas, as a result of issue-specific integration and institutionalisation. To understand the basis for external 
trans-Tasman action in international relations, it is important therefore to pay attention to the intra-regional institutional foundations of the region.

This approach is, as Rüland (2010) notes, one that will fill a gap in the literature on interregionalism. Interregional studies have been dominated by "structural and systemic perspectives" $(2010,1280),{ }^{3}$ with Aggarwal's (2004) multi-level approach (including analyses of domestic, state and regional actors) a rare exception. This leads Rüland to conclude that "more research is needed to assess how, when and to what extent subnational and state actors as well as intra-regional bodies influence the emergence, performance, evolution and decision-making of inter-regional bodies" $(2010,1280)$. This thesis addresses this need by investigating how trans-Tasman intra-regional integration affects cooperation between Australia and New Zealand with third parties in international relations. The following section expands on the approach taken in this study.

\subsection{Explaining DV Variation: Intra-Regional Institutional Trajectory and Interregionalism}

The preceding two sections showed that regional integration can be driven by external as well as internal factors, and that regions are generally understood to require 'actorness' to engage in interregionalism. These previous sections also pointed to a number of gaps or shortcomings in this literature, which this project will help to address. The current section presents the central claim advanced in the thesis.

While forces at the domestic, regional or international level provide the impetus for Australia and New Zealand to cooperate, this thesis posits that it is the particular set of

\footnotetext{
${ }^{3}$ In other words previous scholarship on interregionalism has tended to adopt a "regions-as-units" approach.
} 
institutions developed through trans-Tasman integration that determine how this cooperation emerges, and also why it might occur in some issue areas and not others. This argument rests on two main points. The first is that institutions provide policy makers with a ready-made framework within which to pursue goals. They facilitate decision making, as Douglass North has argued, by reducing transaction costs (North 1992, 1990a, 1990b). They "reduce uncertainty by providing a structure to political, social, and economic exchange" (North 1990a, 182). Simply put: "When transaction costs are significant, then institutions matter" (North 1992).

In the trans-Tasman context, no over-arching set of supranational institutions exists (Schiff and Winters 2003; Severino 2011, xi; Scollay, Findlay, and Kaufmann 2011, 16; 101). Instead, a pragmatic approach has been taken whereby existing Australian federal institutions have been adapted for use to regulate issues relating to trans-Tasman integration. Where necessary, other institutions and arrangements have been established to serve particular purposes (Leslie and Elijah 2011, 15). These institutions are decentralised and issue-specific. They therefore reduce the transaction costs involved in joint cooperation in particular policy areas, enabling policy makers to jointly pursue goals in those areas. This thesis suggests however that while such institutions are issue-specific, they need not be context-specific. Within issue-areas, they can be adapted to new functional environments to achieve the same, or similar, policy goals.

The first part of this project's hypothesis could be used to support a state-centric approach to understanding regional integration; institutions provide a mechanism for policy makers to pursue strategic objectives. The second point on which this project's hypothesis rests however is more supportive of neo-functional or multi-level governance contentions. It proposes that trans-Tasman institutions and arrangements 
play a more active role in driving integration. Drawing from the "cultural approach" of historical institutionalism, this thesis contends that trans-Tasman institutions affect the identities, self-images and preferences of actors. Hall and Taylor suggest that, according to this approach, "The strategies induced by a given institutional setting may ossify over time into worldviews, which are propagated by formal organizations and ultimately shape even the self-images and basic preferences of the actors involved in them" (Hall and Taylor 1996, 9). In this way, institutions can establish cognitive patterns of action that shift the preferences of individuals who interact with them.

Transnational institutions, therefore, encourage cooperation between states by providing a framework through which officials' goals may be pursued. They lower the transaction costs involved in joint action. They can also, however, play an active role. Their members exert their own preferences, and they can also modify the preferences of other actors including national government officials. In the trans-Tasman context, because of the issue-specificity of institutions, this thesis proposes that "actorness" should be understood as an issue-specific rather than general variable. In short, this thesis hypothesises that the single most important factor in determining when and how spillover from internal to external policy cooperation is the issue-specificity of transTasman institutions.

The following section outlines the methodology adopted in this thesis.

\subsection{Research Methodology, Case Selection and Limitations}

\section{Methodology}

In order to answer the empirical research question posed by this thesis, this project uses primary source evidence to accurately reconstruct the two cases. This evidence takes 
the form of archival documents, institutional records, and semi-structured interviews with targeted individuals. Initial research was conducted during a six-month internship at the Asia-Europe Foundation (ASEF) in Singapore from March to September, 2011. Research during this period included a number of formal and informal interviews with staff at ASEF, including with the (then) Executive Director of ASEF Ambassador Dominique Girard. As ASEF serves in some part as a repository of institutional memory for the Asia-Europe Meeting (ASEM) process, it was also possible to access records regarding Australia and New Zealand's membership application that are not publicly available.

Archival research conducted at the New Zealand National Archives in Wellington from October to December 2011 focussed on Australia and New Zealand's relationship with ASEAN. Much of the historical documentation from the 1960s and 1970s has been made fully available, as have more recent records that pertained to areas of technical cooperation between CER and ASEAN during the 1990s. Many of the more recent records, including those relating to strategic or economic considerations - including trade - are not yet publically available however. To supplement these archival records, relevant senior officials in New Zealand and Australia were targeted for semi-structured interviews. Interviewees included but were not limited to members of the Australian Department of Foreign Affairs and Trade (DFAT) and the New Zealand Ministry of Foreign Affairs and Trade (MFAT). Interviews were predominantly conducted on a nonattributable basis, and unless otherwise indicated were confidential. The lack of archival documentation on AANZFTA negotiations shaped the scope of the project to some extent, resulting for instance in a greater focus on the technical aspects of CER-ASEAN relations such as in standard-setting. 


\section{Case selection}

Framing the Australia/New Zealand-ASEAN cooperation and Australia and New Zealand's applications to ASEM as distinct cases enables a systematic approach to analysis that is able to isolate relevant variables. Diachronic variation in the first case (Australia/New Zealand-ASEAN relations) between the 1970s and the 1990s also provides a further triangulation of variables by distinguishing between the transTasman policymaking environment pre- and post-CER. This small- $N$ comparative methodology is appropriate for a project that seeks to test a causal hypothesis for variance in policy choice within a small sample size - namely Australia and New Zealand.

\section{Limitations}

Given the time and space constraints of the Master's thesis, a greater sample size would be impractical - casting the net widely would result in a shallow analysis of a large number of cases. This thesis does not attempt to conclusively test existing theoretical assumptions about regional integration and the development of extra-regional capacities at a macro-level. Rather, this project is motivated by the opportunity to conduct original research on two cases that hitherto have been largely ignored. This project therefore faces the methodological trade-off between depth of analysis and breadth of case selection. Because of the concern for conducting quality, original research, this thesis restricts its analysis to two cases, which it explores thoroughly. This can now be used as a basis for further comparative work. 


\section{$2.5 \quad$ Conclusion}

External trans-Tasman cooperation in the CER-ASEAN case contrasts markedly with the separate approaches taken to ASEM membership. To understand this empirical puzzle this project asks how and why trans-Tasman cooperation in internal policy areas might spill over into cooperation in external policy areas such as foreign or trade policy. This avenue of inquiry relates to scholarship on regionalism and inter-regionalism, which provides clues about how the research problem can be understood. Building on this scholarship, this project posits that while both CER-ASEAN relations and ASEM membership reflect imperatives derived from the international and regional environments, variance between the two cases is explained by the particular structure of existing trans-Tasman institutions. In particular, the de-centralised, issue-specific nature of these institutions made them adaptable for use in CER-ASEAN relations but not in the ASEM case. To evaluate this claim, this project compares the two cases in depth, drawing on archival documentation and key actor interviews.

The following chapter provides the empirical context of the project. 


\section{Three}

\section{Australia and New Zealand: Integration and Economic Opening in Historical Perspective}

"New Zealand and Australia both have bigger fish to fry than each other"

- New Zealand Ministry Official (2011, interview).

\section{Introduction}

Before turning to the two case studies of this project, a measure of empirical context is in order. This chapter provides an historical overview of trans-Tasman integration and New Zealand and Australia's early relations with ASEAN. These two developments are intertwined; they are both products of changing international and domestic environments that encouraged Australia and New Zealand to change historical trading patterns.

On the eve of Australian Federation, New Zealand was invited to join the states and territories of Australia in political union. Although New Zealand declined, the invitation still exists in the preamble to the constitution of the Australian Commonwealth, a testament to the historical ties between the two countries (McLean 2003). Over a century later, political integration seems an unlikely prospect and overt discussions about political union are dismissed by politicians. Economic integration on the other hand has advanced to such a degree that the World Trade Organisation in 1996 declared the Australia-New Zealand Closer Economic Relations Trade Agreement (ANZCERTA, or commonly, CER) "among the most comprehensive trading agreements in the world" (World Trade Organization 1996). The Trans-Tasman relationship, moreover, goes much deeper than a trade agreement. Since CER's entry in 1983, economic integration between Australia and New Zealand has developed a far-reaching agenda that now includes the ambitious goal of creating a Single Economic Market (SEM). 
The process of economic integration between Australia and New Zealand occurred in parallel with an effort to engage with new economic partners elsewhere. In particular, the two countries recognised the economic potential of the Asian region. They began to forge ties with emerging Asian economies (including ASEAN), which would lay the foundation for trade agreements such as AANZFTA in years to come. These two processes did not occur in isolation. At the international level, the loss of the British export market encouraged Australia and New Zealand to consider alternative trading partners in an increasingly turbulent international economic environment (Bollard 1986). Trans-Tasman integration as well as Australia and New Zealand's "turn" towards Asia can therefore be understood with reference to the "contagious" impact of economic regionalism, (Baldwin 1997, 1995; Mattli 1999). NAFTA was also motivated by domestic concerns. In particular it was motivated by a concern to gain access to the Australian market for New Zealand's paper industry (Guest and Singleton 1999).

The remainder of this chapter proceeds in two principal parts. The first describes the evolution of trans-Tasman economic integration and the particular historical context in which this happened. The institutional arrangements of trans-Tasman integration are also discussed, the particular functioning of which has played a central role in furthering trans-Tasman integration.

The second presents archival research on Australia and New Zealand's early engagement with the Association of South East Asian Nations (ASEAN). Australia and New Zealand had convergent approaches towards relations with ASEAN from the 1970s. There was no formal cooperation between the two however, despite some indication that New Zealand may have wished to pursue this option. 


\subsection{Trans-Tasman Integration: International and Intra-Regional Drivers}

During the twentieth century, the trading relationship between Australia and New Zealand went from one of economic antagonism and competition to deep economic integration. This dramatic evolution of trans-Tasman economic relations was set in motion by changes in the international environment and in Australia and New Zealand's respective domestic environments, not least of which was the congruence of a neoliberal (de-)regulatory philosophy on both sides of the Tasman. Once established, integration was facilitated and indeed encouraged by the trans-Tasman institutional arrangements that had been established during initial efforts at economic integration.

\section{The genesis of trans-Tasman economic integration}

Since the late 1800s, similar export profiles, close trade with Britain and competitive domestic policies meant that trans-Tasman economic relations were at times rancorous. Australian subsidies of dairy exports were in effect after 1926, while New Zealand protected secondary industries in competition with Australia. This resulted in "mutual criticism in regard to dairy produce"; the protectionist attitude on both sides of the Tasman "did not create harmony in trading relations between the two countries" (Bentick 1962, cited in Fenton 1968,6). Reliance on the UK export market was a clear factor in this competitive relationship. In 1900, Australia's merchandise exports to the UK were nearly $60 \%$ of its total exports; in the 1930 s, this figure generally remained above 50\% until World War II (Figure 1). UK-bound Australian exports dropped during World War II, and although they recovered after the war and during the 1950s, have trended down since then. Australian exports to New Zealand overtook exports to the UK for the first time in the mid-1970s. 


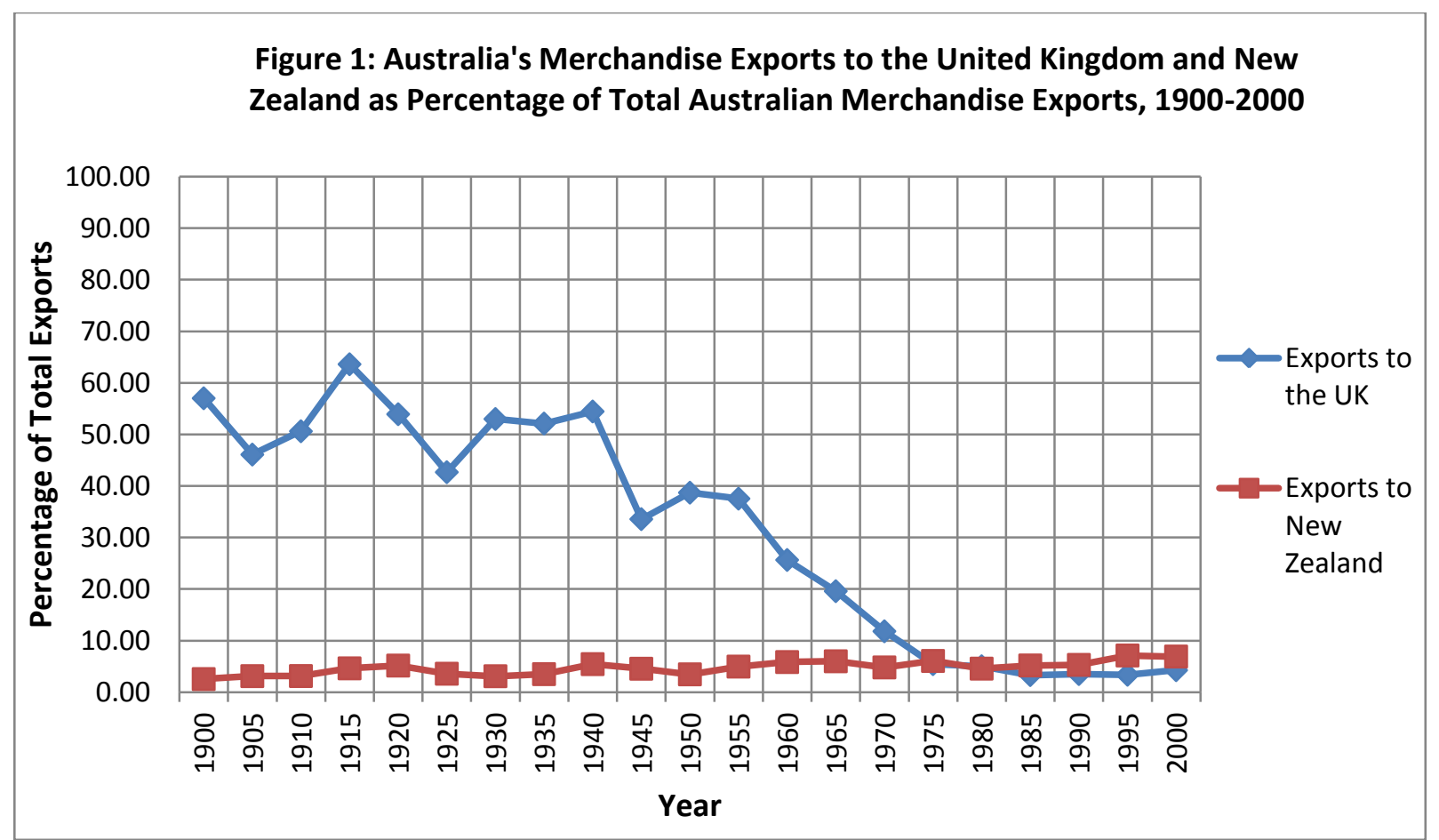

Source: (Australian Bureau of Statistics 2001, 1996, 1992, 1986, 1981, 1975; Commonwealth Bureau of Census and Statistics 1971, 1962, 1966, 1930, 1953, 1936, 1939, 1945, 1956, 1926, 1921, 1931, 1908, $1916,1912)$

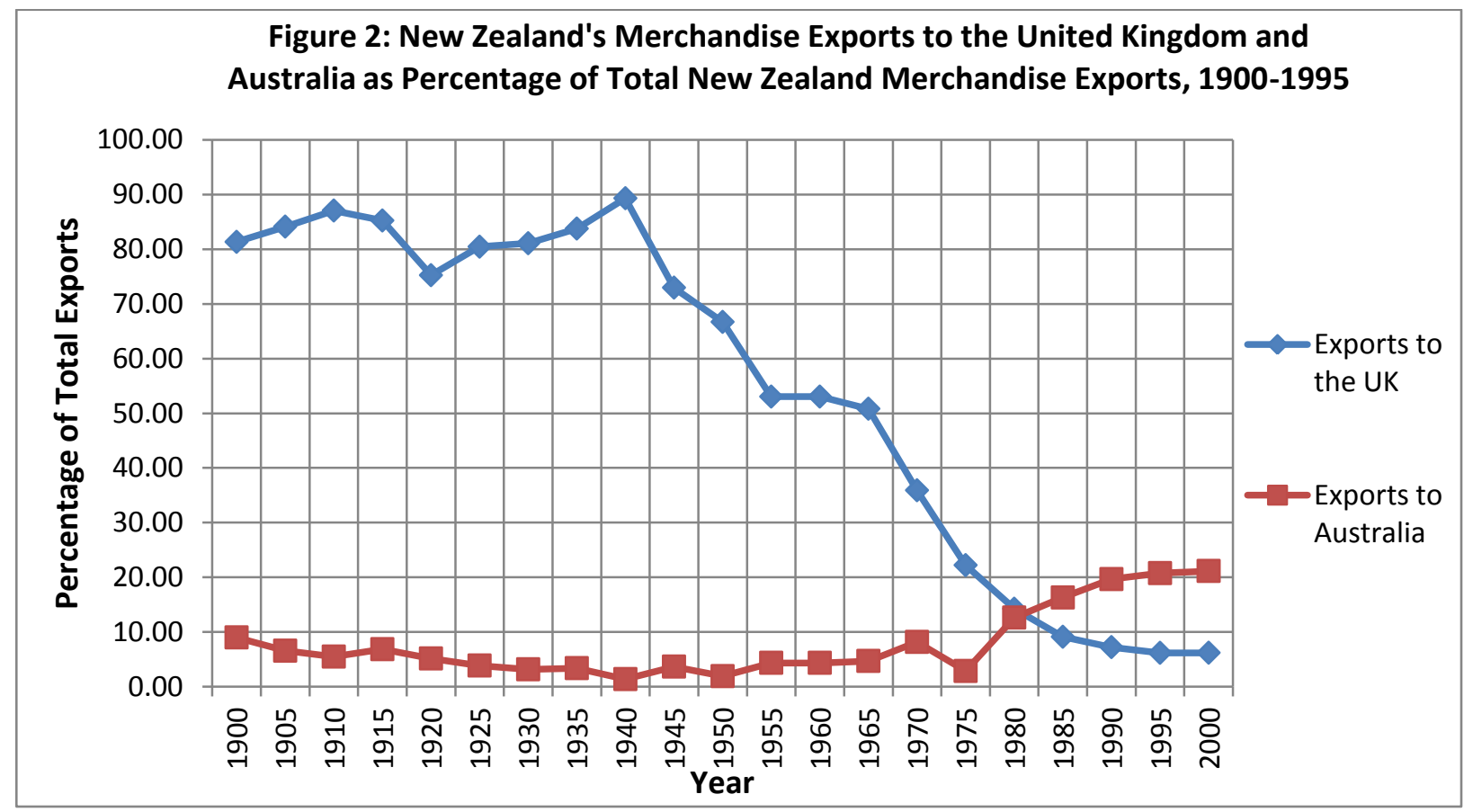

Source: (Statistics New Zealand 1996, 29; 2001, 95-96). 
On the other side of the Tasman, New Zealand maintained a much longer reliance on the UK market (Figure 2). In 1900 New Zealand's merchandise exports to the UK were 81\% of its total, compared to just below $9 \%$ of merchandise exports destined for Australia the highest proportion of New Zealand exports to Australia until the late 1970s. The proportion of these exports to the UK remained extremely high until World War II, reaching $89 \%$ in 1940 . It was only in the 1960 s that merchandise exports to the UK dropped below 50\%, and they have trended sharply downward since then. At the same time, merchandise exports to Australia remained low in relative terms until the late 1970s - despite early trans-Tasman liberalisation. Australia overtook the UK as a destination for New Zealand merchandise exports in the early 1980s. In this context of similar export profiles and reliance on the UK market, trade competition between Australia and New Zealand during the first half of the Twentieth Century is readily understandable. What is less immediately apparent is how the relationship was transformed to one of close integration.

The establishment of the European Economic Community by the Treaty of Rome in 1957 and the UK's 1960 application for membership signalled a looming economic threat to the economies of the British Commonwealth. Although accession would not take place until 1973, the UK's lot was clearly being thrown in with Europe. With entry to the EEC, the UK would no longer be able to uphold the same preferential trading agreements it had maintained with its former colonies. Australia and New Zealand were accordingly forced to consider alternative markets for their goods, and this included strengthening trade with one another. This is a clear validation of the "contagion" or "domino effect" thesis of regional economic integration (Baldwin 1995; Baldwin and Jaimovich 2010). The implied diversionary effect of the UK's entry into a regional trading agreement (the 
EEC) forced Australia and New Zealand to defensively establish a regional trade agreement, even though this was inconsistent with their previous trade pattern.

Signed in 1965 and introduced in 1966, the New Zealand-Australia Free Trade Agreement (NAFTA) was Australia and New Zealand's response to the changing international environment. The agreement also reflected the outcome of efforts by the New Zealand pulp and paper industry to secure a market for its exports, which by the 1960s had become a leading exporter of manufactured products for New Zealand (Guest and Singleton 1999). In terms of trade creation, NAFTA had mixed success however. One cause of this was the 'positive list' approach to goods liberalisation that it adopted. Tariffs were reduced and removed only on a limited number of goods, and there was no automatic mechanism to add new goods to this list. Bi-annual meetings were required to progress liberalisation, which was a cumbersome and bureaucratically demanding process.

While NAFTA did not establish an effective free trade area, it was successful in regularising contact between Australia and New Zealand at the Ministerial and officials level through its bi-annual meetings. The institutionalisation of regular trans-Tasman relations facilitated discussion on advancing the relationship, while familiarising Australian and New Zealand officials with one another. When developments in the international environment encouraged a re-evaluation of Australia-New Zealand economic relations, the framework for a trans-Tasman response was already established.

The UK's application to enter the EEC had provided the impetus for initial liberalisation and in 1973 the UK finally achieved accession. 1973 also saw the OPEC oil crisis erupt, triggering monetary and supply shocks that destabilised global markets. In response to 
these events, New Zealand and Australia signed an agreement in the same year to ensure tariff rates between them would be kept as low as possible (Mein Smith 2007, 164). Two years later, New Zealand's trade deficit - two thirds of which was to Australia - had "ballooned" to the point where New Zealand sought trade credit from its partner. It was at the annual NAFTA ministerial meeting that the Australian Minister for Overseas Trade, Frank Crean, proposed that "something [would] have to be done for New Zealand", and options for NAFTA's reform were considered (Mein Smith 2007, 164).

By the end of the 1970s, it became increasingly clear that NAFTA was not a viable framework for liberalisation however. There was mounting frustration on both sides of the Tasman at protectionist measures that the agreement had been unsuccessful in removing - especially in Australia over quantitative restrictions imposed under New Zealand's import licensing system (Gold and Thakur 1982, 402). In fact, Bollard and Mayes (1992) suggest that the extent to which NAFTA was a trade-creating agreement is questionable. They note that trade in scheduled goods was the same in 1973-1974 as it was when the agreement was signed in 1965 (1992,199). By the end of the 1970s, although quantitative restrictions and tariffs had been removed on $80 \%$ of transTasman trade, there was growing appreciation that a new approach to trans-Tasman integration was desirable (Scollay, Findlay, and Kaufmann 2011, 22; Woodfield 2008). NAFTA's inefficiency meant that there were substantial internal motivations to reform NAFTA or to pursue liberalisation within an alternative framework.

To discuss the future of the economic relationship there was an increasing volume of trans-Tasman exchange during the late mid- to late-1970s. In 1976, Australia and New Zealand agreed to extend NAFTA until 1985.4 In a three-week trip over March and April

\footnotetext{
4 The agreement had initially been intended to last for ten years.
} 
Brian Talboys, the New Zealand Foreign Minister, toured Australia to drum up enthusiasm for the trans-Tasman relationship. During this tour, he and the Australian Prime Minister Malcolm Fraser discussed various avenues for future Australia-New Zealand economic cooperation and announced the 1978 Nareen declaration, affirming Australia and New Zealand's mutual commitment to the trans-Tasman relationship and to the broader Asia-Pacific region. The declaration also outlined the two countries' resolve to adopt further liberalisation to ensure the health of both economies - Mein Smith suggests that Canberra's subtext was that New Zealand might contribute more to defence if its economy was in better shape (Mein Smith 2007, 165-166).

A new era of trans-Tasman relations: ANZCERTA

Despite the impetus for NAFTA reform on both sides of the Tasman, no real progress was made until 1979 when developments on the international stage provided the tipping point to set CER in motion. In addition to pursuing trans-Tasman integration through NAFTA, Australia and New Zealand had become champions of economic liberalisation at the multilateral level and lobbied hard at the GATT for tariff reduction on agricultural products. During the 1973-1979 Tokyo round of GATT negotiations, Australia and New Zealand were unsuccessful in pushing for tariff reductions on agricultural products, due largely to resistance from the US and the EEC. As suggested by Bhagwati (1993) and Krugman $(1993,1991)$, the failure of multilateralism can act as a further incentive for regional integration. This was certainly the case for CER and it was once again within the institutional framework provided by annual NAFTA ministerial talks that action on trans-Tasman integration was able to be taken.

On returning from the unsuccessful conclusion of the negotiations, Australia's Deputy Prime Minister Doug Anthony attended NAFTA talks on 10 April 1979 at which he 
initiated a process of trans-Tasman discussion that would ultimately lead to CER. Despairing at the banality of issues discussed at the NAFTA meeting, Anthony suggested the agreement had reached the end of its utility and that a new arrangement between Australia and New Zealand was needed to mitigate the failure at the GATT; Australia and New Zealand would have to "hold hands" (Mein Smith 2007, 167). The following day, Anthony met with the New Zealand National Party Prime Minister Robert Muldoon, and it was at this meeting that the roadmap for CER was substantively laid out (Mein Smith 2007, 167).

The first steps towards CER taken in 1979 were followed by a Joint Prime Ministerial Communiqué issued in March 1980 by Prime Ministers Malcolm Fraser and Robert Muldoon, which publicly called for "closer economic relations" between Australia and New Zealand (Ministry of Foreign Affairs 2005). Over the next three years negotiations took place on a new trans-Tasman trade agreement. In 1983 ANZCERTA came into force. Wise to the organisational and bureaucratic issues encountered with NAFTA, Australian and New Zealand officials made CER a bureaucratically streamlined and explicitly outward-looking agreement. One commentator notes that "CER was planned as a trade agreement that would require low maintenance and a minimum of bureaucratic resources" (Lloyd 1995, 271). CER also reflected the nascent neoliberal reformism that was taking hold on both sides of the Tasman; it was an open, GATT-consistent regional trading agreement. As opposed to its predecessor, CER functions with a "negative list" meaning that only those products explicitly marked for exclusion (and subject to 
"modified agreements") were not subjected to quantitative easing and progressive tariff reduction and removal. ${ }^{5}$

The first major review of CER in 1988 was a milestone in trans-Tasman integration. As a result of the review, it was decided to bring forward the CER agenda by extending liberalisation to all goods including those subject to "modified agreements". This was achieved in 1990, five years ahead of the initial schedule. 1988 also marked the introduction of the CER Trade in Services Protocol. In all, the 1988 review led to the extension of CER to "services and the harmonization of quarantine restrictions, business law, technical barriers, customs policies and practices, state government purchasing and export restrictions" (Bollard and Mayes 1992, 199).

This integration coincided with a spate of domestic reforms that saw the unilateral adoption of market liberal policies by governments in both Australia and New Zealand. Inspired by the United States and the United Kingdom, Australia and New Zealand adopted neoliberal reform and re-oriented their trade and foreign policy towards the Asia-Pacific. They continued their strong advocacy for (especially agricultural) trade liberalisation through the GATT/WTO mechanisms, as well as broadly supporting open regionalism in the Asia-Pacific through such fora as the Asia-Pacific Economic Cooperation (APEC) initiative in 1989 (Leslie and Elijah 2011, 12). Trans-Tasman integration was seen as a complement, rather than a hindrance, to these broader efforts at regional and multilateral integration, in opposition to European integration which was perceived by Australia and New Zealand in the 1970s and 1980s as overly bureaucratic and trade diverting (Leslie and Elijah 2011, 11-12).

\footnotetext{
5 These exceptions were largely the result of domestic opposition from the dairy industry in Australia and manufacturing sector in New Zealand.
} 
By 1990, there existed a "framework for economic integration between Australia and New Zealand" that has become the "basis for the integration agenda that has been pursued by the two governments since that time" (Scollay, Findlay, and Kaufmann 2011, 29). A progressive process of deepening trans-Tasman integration has occurred. Between the two countries there now exists free trade in goods and services; a broad regime for mutual recognition of goods, services and qualifications; agreements on sanitary and phyto-sanitary measures; unrestricted travel; automatic welfare benefits for Australian citizens residing in New Zealand and a streamlined process for New Zealanders to receive similar benefits in Australia; and portability of pensions.

Since 2004 the two countries have been committed to the implementation of a Single Economic Market (SEM) initiative, which would result in a near seamless merging of the two economies (Scollay, Findlay, and Kaufmann 2011, 3). In 2009 the two governments outlined seven principles, which would guide the process towards developing a single economic market. These include an affirmation that "the two countries should seek to strengthen joint capability to influence international policy design" and that the two would "move from weighing strictly national benefits in policy development to consideration of net trans-Tasman benefits" (Power 2009). This constitutes a clear recognition of the broader regional and global context in which trans-Tasman integration occurs.

Trans-Tasman institutions: pragmatic supranationalism, limited spillover

In 1992 Bollard and Mayes had concluded of CER that there was "quite a resemblance to the sorts of issues discussed in the completion of the Internal Market in Europe, although without the supranational framework" $(1992,199)$. While they are correct that CER possesses no single, over-arching set of supranational institutions as in the EU, 
during the early 1990s CER did in fact begin to develop regional institutions with supranational characteristics. These institutions exhibit both similarities to and differences from those of the EU, and reflect the idiosyncratic adaptation of existing institutions for trans-Tasman regulatory needs (Leslie and Elijah 2011).

In large part, these institutions had their origins in Australia's federal system, and consisted of the issue-specific Ministerial Councils that grouped together State, Territory and Federal Ministers. Reform of Australia's federal structures launched with Prime Minister Bob Hawke's “New Federalism” established the Special Premier's Conference (SPC), followed in 1992 by the Council of Australian Governments (COAG), an overarching federal institution that housed the Ministerial Councils as subsidiary decisionmaking bodies. This reform was undertaken to overcome a range of coordination problems within the Australian Federation that resulted from cross-cutting jurisdictions and a sometimes unclear distribution of regulatory authority (Painter 1998, 6-7). The upshot of this reform was an informal institutional structure that enabled constructive and non-confrontational collaboration with the federal structure (Painter 1998, 2001; Hollander and Patapan 2007).

New Zealand had participated informally in the Ministerial Councils for decades, and with their reform, the councils provided an available institutional structure for transTasman governance. In issue-areas that span the Tasman, New Zealand has full participation and voting rights, and the Ministerial Councils have the ability to directly implement issue-specific law (regulations) in New Zealand as well as Australia. In certain instances, the Ministerial Councils effectively have supranational capabilities, 
implementing regulations on both sides of the Tasman through qualified majority vote (Commonwealth-State Relations Secretariat 2009, §2.16). ${ }^{6}$

The 1988 Review of CER had determined that the institutional arrangements for transTasman integration were to remain disaggregated rather than becoming centralised under a "single instrument", as was New Zealand's preference (Leslie and Elijah 2011, 15). This means that while CER is the driving force of trans-Tasman integration, transnational institutions have emerged that do not fall directly under the CER umbrella. These institutions have developed through a process of spillover that has been pragmatic and issue-specific. As a result of work on technical barriers to trade outlined in the 1988 Review, an Agreement on Standards, Accreditation and Quality (ASAQ) came into force in October 1990, and the Joint Accreditation System of Australia and New Zealand (JAS-ANZ) was established in 1991 as a further outcome. JAS-ANZ, a semiautonomous institution, has regulatory authority in both countries, as does Food Standards Australia New Zealand (FSANZ). These institutions are the result of a pragmatic approach to integration that has seen limited instances of spillover in specific issue areas. Their supranational qualities are restricted to particular issue areas, meaning that potentially politically challenging questions about issues like sovereignty have largely been avoided. The brand of supranationalism developed during the course of trans-Tasman integration is not generalised as in the EU, but is instead issue-specific.

Trans-Tasman economic relations therefore underwent a transformation during the Twentieth Century. After defensive domestic policies in the first half of the century, the two countries gradually sought to integrate their economies. Driven by the need to diversify their export profiles and their trading partners, Australia and New Zealand

\footnotetext{
${ }^{6}$ This applies predominantly to issues relating to the Trans-Tasman Mutual Recognition Arrangement (TTMRA).
} 
overcame a history of economic antagonism to reach a point where the goal is expressly one of mutual net benefit in the broader international context. International factors played an essential role in this story. The entry of the UK to the EEC and the failure of multilateral liberalisation in key sectors provided important motivation at crucial points in the relationship to advance integration. Domestically, industry interests and frustration over the pace of liberalisation also contributed. Integration did not always proceed smoothly however. NAFTA proved cumbersome, and integration advanced slowly. This thesis suggests that an important achievement of NAFTA was the formalisation of relations between decision makers on both sides of the Tasman in annual talks. Using this framework as a launching pad, a more bureaucratically flexible agreement - CER - was able to be devised. The internal institutions of CER ensured that practical and achievable policy choices could be made where the unwieldy structure of NAFTA had been a constraint. CER's institutions provided, moreover, an inherent agenda for further liberalisation.

The process of trans-Tasman integration reflects the importance of available institutional structures (NAFTA's Ministerial meetings) in facilitating decision making between Australia and New Zealand. Because of, not despite, the dense bureaucracy of NAFTA, further trans-Tasman integration was enabled. NAFTA's regularised meetings although tedious - had brought key policy makers on both sides of the Tasman into a close, working proximity that facilitated strategic decision making. NAFTA also began the process of binding Australia and New Zealand's economies together, helping to overcome previous competition and reinforce Australia and New Zealand's sense of shared fate in the region. When New Zealand's balance of payments deficit soared in the mid-1970s, the proposal to re-evaluate NAFTA came not from New Zealand, but from 
Australia (Mein Smith 2007, 164). Building on NAFTA's failures, CER emerged as a highly functional, outward-looking agreement whose institutional arrangement was similarly essential in encouraging further trans-Tasman integration.

Do the drivers of trans-Tasman integration also shape Australia and New Zealand's cooperation with third parties in international relations? The following section provides an overview of Australia-ASEAN and New Zealand-ASEAN relations. It shows that the "contagious" drivers of trans-Tasman economic integration also encouraged Australia and New Zealand to seek out relations with ASEAN, though no formal trans-Tasman policy coordination over ASEAN took place.

\subsection{Australia, New Zealand and ASEAN - Historical Policy Convergence}

Trans-Tasman integration was part of a broader re-orientation of the Australian and New Zealand economies that included a concerted effort to establish and strengthen economic ties with new trading partners. This section demonstrates that from the early stages of both countries' relations with the Association there is evidence of policy convergence between Australia and New Zealand on ASEAN. This is particularly obvious from the New Zealand side, although certain ASEAN states also made an effort to ensure that ASEAN policy towards Australia and New Zealand was similar. Some of the same forces that acted as drivers of trans-Tasman integration also motivated Australia and New Zealand to establish relations with ASEAN and to seek membership in the regional institutions of the Asia-Pacific. There is some evidence of momentum to establish a formal joint trans-Tasman approach to relations with ASEAN, but there is no indication that this suggestion bore fruit prior to the 1990s. It seems likely that this was because until CER developed there was no appropriate trans-Tasman mechanism to accommodate such cooperation. The section concludes that the impetus for joint 
cooperation was present in the 1970s, but the framework was lacking. This raises the central question of how and why trans-Tasman integration could spill over into joint Australia-New Zealand cooperation with external partners, which is addressed in Chapters Four and Five.

Following ASEAN's formation on the $8^{\text {th }}$ of August 1967, in the 1970s the Association began to establish formal relations with external partners. This timing coincided with Australia and New Zealand's realisation of the need for new trading partners. The OPEC oil crisis and the UK's entry into the EEC both took place in 1973, and efforts were being made under NAFTA to increase trans-Tasman liberalisation in response (Mein Smith 2007). Australia and New Zealand were ready to seek new economic partnerships.

Initial Australian and New Zealand relations with ASEAN were established primarily on a bilateral basis with individual ASEAN countries, but during the early 1970s this began to change. In November of 1973, it became apparent to officials at the New Zealand High Commission in Singapore that an invitation from the Malaysian government would be issued to Australian officials for a study team to attend a meeting with the ASEAN Secretaries-General in February 1974, "to discuss with the ASEAN Secretaries-General the scope for involving Australia in ASEAN development projects" (Ministry of Foreign Affairs 1973a). The invitation of Australia caused some consternation in Wellington; a reply to the New Zealand High Commission in Singapore on Christmas Eve noting, "Clearly this is exactly the kind of development we would wish to be associated with" (Ministry of Foreign Affairs 1973c, §1). Officials in Wellington elaborated, "We have no rpt [sic] no desire to horn in on any bilateral Australian-ASEAN gathering to discuss specific projects. But even if we are both to develop our cooperation with ASEAN 
through separate consultations of this type, we would still see coordination advantages in attending each other's meetings" (Ministry of Foreign Affairs 1973c, §2).

After discussing with the Singaporean Permanent Secretary at the Ministry of Foreign Affairs G. E. Bogaars, the New Zealand High Commission in Singapore clarified that the meeting would not be exploratory in nature. New Zealand officials in Singapore expressed Wellington's keen interest in pursuing a similar relationship with ASEAN to Australia, but this proved difficult to implement. The High Commission in Singapore reported, "Bogaars commented that he was sure an expression of New Zealand interest would be welcome, but so far as the first meeting was concerned he felt it better to 'see what the Australians come up with"' (Ministry of Foreign Affairs 1973b). The New Zealand High Commission in Canberra confirmed that the Australian invitation had not been solicited, that the meeting would be "purely exploratory" and that the Australians would not be attending an official ASEAN event. Rather, they would be consulting with the ASEAN Secretaries-General at a preliminary meeting (Ministry of Foreign Affairs 1974a).

Wellington was encouraged by Bogaars and contacted the relevant ASEAN counterparts with an indication of interest in establishing relations with the Association. This approach proved insufficient however. At a meeting of the Secretaries-General in Kuala Lumpur in early 1974, the matter of relations with New Zealand had been raised. The Malaysian Secretary General, Yusof Bin Ariff had strenuously objected to New Zealand's informal approach. Instead, he argued, New Zealand should write formally to Adam Malik, the Chairman of ASEAN's Standing Committee and the Committee would deliberate on cooperation with New Zealand. Despite objection from several ASEAN 
members to the formality of this approach, it was ultimately agreed that this should be the course of action taken by New Zealand (Ministry of Foreign Affairs 1974b).

Australia would become a Dialogue Partner of ASEAN as of April 1974, the first country to do so (Ravenhill 1998). For New Zealand, things did not happen as quickly. Wellington duly submitted a letter to Malik, but approval of formal ASEAN-New Zealand relations was slow in eventuating. Throughout 1974, an on-going exchange of communications between the New Zealand High Commission in Singapore and the Ministry of Foreign Affairs in Wellington details the efforts of New Zealand to advance relations with ASEAN along the same lines as Australia. An internal Ministry of Foreign Affairs telegram dated 23 July 1974 notes New Zealand was "still interested in establishing joint cooperative efforts with ASEAN similar to those the Australians were now discussing" (Ministry of Foreign Affairs 1974d). Singapore, which had been delegated the liaison responsibilities for New Zealand, acted as an important advocate for New Zealand's interests within ASEAN. Singaporean officials agreed with the sentiment that Australia and New Zealand should be treated similarly within ASEAN; they were "concerned that New Zealand and Australia should be seen to receive equal treatment [by ASEAN]" (Ministry of Foreign Affairs 1974c).

Ultimately, New Zealand's Dialogue Partner status was conferred in February 1975, the year after Australia. It is after this point that discussion began to truly develop into areas of substance. The first ASEAN-New Zealand Meeting took place in Wellington from the $15^{\text {th }}$ to $16^{\text {th }}$ July 1975 ; despite previous invitations this was the first visit of the Secretaries-General to New Zealand. At the meeting, five areas of cooperation were discussed, each of which was to be coordinated primarily with one of the five ASEAN members. Animal husbandry; dental health; forestry; the end-uses of ASEAN timber in 
New Zealand; and trade expansion were all raised as areas in which ASEAN wished for assistance from New Zealand. While these areas of cooperation were all largely technical, work on trade expansion - coordinated with Singapore - laid important groundwork for future economic relations. ASEAN states were concerned with New Zealand's strict import licensing system and high external tariffs, while New Zealand's General Scheme of Preferences (GSP) was also presenting obstacles to trade. With the balance of trade with ASEAN firmly in New Zealand's favour, it was considered that discussions on trade expansion would be "futile" without changes to New Zealand's import licensing and GSPs (Ministry of Foreign Affairs 1975, §12).

A Joint Trade Study Group was established to investigate ASEAN-New Zealand trade expansion issues, the progress of which was followed not only in Wellington but also in Canberra. Internal New Zealand Ministry communication signals the interest that both countries had in keeping abreast of one another's developments with ASEAN. An internal New Zealand Ministry telegram from Wellington to Canberra notes, "We would be grateful for your comments on the state of play in Australian preparations for their forthcoming officials meeting with ASEAN to discuss trade and other aspects of economic cooperation between them" (Ministry of Foreign Affairs 1977b). The New Zealand High Commission in Canberra reported in response, "DFA [Australian Department of Foreign Affairs] expects to be ready for a meeting with senior ASEAN officials to review the relationship by about May, and would be most interested in how our JTS Group goes" (Ministry of Foreign Affairs 1977a).

Informal coordination between Australia and New Zealand was evident, and there is also some indication that Wellington viewed more formal cooperation with Canberra as a means of achieving mutual goals with ASEAN. A fax from the New Zealand High 
Commission in Canberra back to Wellington dated 26 September 1978 reveals New Zealand's thinking at that time. The fax was sent in the context of perceptions that Australia's relationship with its ASEAN partners was suffering - that politically there was a "tide in ASEAN countries moving against Australia", which itself faced challenges from the rising importance of other regional states such as Japan (Ministry of Foreign Affairs 1978). The author of the fax goes on to encourage the idea of combined AustraliaNew Zealand efforts with ASEAN. It is worth quoting at length as this is not a publicly available document:

In the current situation, where Australia is heavily preoccupied with ASEAN, New Zealand figures only occasionally. There is no evident feeling, beyond a little which we may have generated ourselves, that Australia is in the same boat as New Zealand over this, nor that cooperation with New Zealand might assist the resolution of Australia-ASEAN difficulties (although one source in the Department of Industry and Commerce is an exception - see our 2214 entitled "NAFTA Discussions with Morton"). But the situation is fluid and the Australians would be susceptible to ideas - provided these give them something to chew on. It is clear that most of them are not going to be attracted to general assertions that if we work together, and particularly if we improve our joint and integrated economic strength, we will be better able to meet ASEAN demands than we can separately and individually, unless such propositions are fleshed out. There is a danger that such a view will seem as simply another way of telling Australia it ought to expand NAFTA. We agree with your judgement that developing Australia-New Zealand cooperation over ASEAN is of major significance, even to direct A-NZ bilateral relations, and suggest accordingly that work on the potential trilateral relationship proceed quickly in tandem with your New Zealand-ASEAN review (Ministry of Foreign Affairs 1978, §. Emphasis added).

This fax reveals important elements of the Australia-New Zealand and Australia/New Zealand-ASEAN relationships in the period leading up to the introduction of CER. New 
Zealand obviously favoured collaboration with Australia on an approach towards ASEAN, seeing advantages in this for both countries. Australia on the other hand apparently saw its own situation and relations with ASEAN as independent and separate from that of New Zealand. Coordinating trans-Tasman relations with ASEAN was not an obvious policy response for Australia, while establishing more formalised cooperation seems to have been considered by New Zealand to be the means to achieving strategic interests in both countries' relations with ASEAN. In this respect, parallels between Singaporean and New Zealand efforts to establish a coherent approach to ASEANAustralia/ New Zealand relations may reflect similarities in the positions of both countries - smaller states in regional groupings, which are vulnerable to the actions of their larger neighbours and therefore seek more formalised collaboration at the regional or multilateral level.

By suggesting that Australia might understand proposed trans-Tasman cooperation over ASEAN as a New Zealand attempt to deepen NAFTA, the fax also reveals an important and accepted - relationship between regional integration and policy convergence at the international (or inter-regional) level. It is telling that this approach was at that stage considered "trilateral". Clearly the relationship between Australia and New Zealand had not deepened or broadened to the point where the idea of a group-to-group relationship with ASEAN could be entertained.

The early Australia-ASEAN and New Zealand-ASEAN relations therefore demonstrate certain recurring themes in this study. Australia and New Zealand turned towards relations with ASEAN at an important juncture in their history. Economic insecurity in a changing international environment prompted a reconsideration of the future of both countries. This future lay in deeper economic relations with Asia. Australia and New 
Zealand were clearly unwilling to be excluded from ASEAN-based developments in the region and saw the potential for future cooperation with ASEAN. Again, the "contagion" thesis of regional economic integration seems to have been vindicated by Australia and New Zealand's desire to establish relations with each other and with ASEAN.

Australia's ability to forge its own path in the region is obvious. Without the efforts of Australia to first establish official dialogue relations with ASEAN, it is questionable whether New Zealand would have been willing or able to subsequently do so as well. Early Australia-ASEAN and New Zealand-ASEAN exchanges also reveal the nascent foundations of the group-to-group relations of the 1990s however, especially evident in Wellington's efforts to coordinate its ASEAN policy with Australia. Even if this tendency was not reciprocated, it established a cognitive and organisational precedent for later trans-Tasman cooperation on ASEAN. NAFTA had provided an institutional framework within which to pursue trans-Tasman economic liberalisation and to formulate CER as a replacement agreement; it did not provide a trans-Tasman mechanism to enable Australia-New Zealand cooperation with ASEAN, nor was there an alternative set of trans-Tasman institutions available to do so. It would only be with the deeper integration of Australia and New Zealand and the development of attendant transTasman institutions that cooperation with an external partner could become a viable policy choice.

\subsection{Conclusion}

This chapter has demonstrated how in both an intra-regional and a foreign policy context, Australia and New Zealand were deeply affected by a changing international environment in which economic regionalism was becoming an important phenomenon. The first section provided a brief overview of trans-Tasman economic integration. It 
showed how the UK's entry into the EEC as well as domestic economic changes induced Australia and New Zealand to overcome decades of economic competition with one another. The institutionalisation of trans-Tasman meetings under NAFTA, although bureaucratically demanding, enabled decision makers on both sides of the Tasman to be in regular contact and ultimately to implement CER. Throughout the history of both NAFTA and CER, the availability of intra-regional institutions has played a determinative role in shaping trans-Tasman integration.

The second part of the chapter demonstrated how the same "contagious" international forces encouraged Australia and New Zealand to seek relations with ASEAN. Although there was no formal instance of trans-Tasman cooperation with ASEAN, there was substantial informal policy coordination and convergence. This convergence laid an important foundation for closer Australia-New Zealand cooperation regarding ASEAN, which was enabled following an acceleration of trans-Tasman integration. It is through the CER Agenda that both regional and inter-regional goals were able to be achieved.

The following two chapters turn substantively to address the central research focus of this thesis. How and why can trans-Tasman integration spill over into external transTasman cooperation with third parties in international relations? 


\section{Four \\ The ASEAN-Australia-New Zealand Free Trade Agreement}

"The way I saw it was that we may only have one shot at this. And if we don't nail it now, we may not get another opportunity for quite a while." - Michael Mugliston, Australian lead negotiator on AANZFTA (2011, interview)

“We haven't gone down the joint approach with the big players. ASEAN was different because of the history that we've had... We don't have that kind of history in terms of talking with those other players about Free Trade or engagement." - David Taylor, New Zealand Ambassador to ASEAN (2011, interview)

\section{Introduction}

Why did Australia and New Zealand cooperate on AANZFTA? Policy convergence on ASEAN is in evidence from at least the 1970s, but this never resulted in formal relations on a region-to-region basis. More recently, Australia and New Zealand's independent applications to ASEM add to the list of separately negotiated agreements in the 1990s and 2000s - such as the New Zealand-China and Australia-China FTAs - that indicate that trans-Tasman cooperation with third parties should not be assumed. What makes AANZFTA different?

Along with Chapter Five, this chapter tests the central claim of this thesis: that internal trans-Tasman policy cooperation spills over into external cooperation as a function of available intra-regional institutions. This chapter demonstrates how trans-Tasman institutions facilitated and indeed encouraged CER-ASEAN relations to develop and deepen in the 1990s, and how this history of cooperation led to Australia and New Zealand accepting joint negotiations on AANZFTA. 
It proceeds in three main sections. The first section outlines the formal negotiating process for AANZFTA, which was explicitly interregional in character. This section provides the empirical context for the remainder of the chapter.

The second section discusses how the CER-ASEAN relationship emerged in the mid1990s. It highlights the central role played by a number of trans-Tasman institutions that were formed in the early 1990s as part of the decentralised institutional architecture of trans-Tasman integration. The issue-specificity of these institutions channelled CER-ASEAN cooperation in these particular areas, which helps to explain why and how spillover occurred in some areas and not others. Previous trans-Tasman cooperation in the issue areas governed by these institutions had established a precedent as well as a framework for CER-ASEAN cooperation.

A third section examines deepening and broadening CER-ASEAN interregionalism during the 1990s. Inter-institutional links resulted in deepening cooperation between the two regions in issue areas supported by existing trans-Tasman institutions. This deeper cooperation spilled over into new issue areas, especially once the aim of liberalisation between the two regions began to be considered. This section therefore elaborates on the process of spillover from internal trans-Tasman cooperation to external CER-ASEAN cooperation. It also asks who drove spillover. Trans-Tasman institutions provided a ready-made structure for officials to conduct relations, but these joint institutions also allowed non-governmental trans-Tasman actors to participate in CER-ASEAN relations. This section concludes that CER-ASEAN integration took place on multiple levels, driven by a range of actors whose preferences, perceptions and interests were influenced by the particular institutional environment established by transTasman integration. 


\subsection{AANZFTA: From Proposal to Signatures}

This first section presents an overview of the FTA process from proposal to final signatures, thereby providing the context in which to understand Australia-New Zealand cooperation on the negotiations. AANZFTA was proposed in an environment of growing economic competition and was part of an effort on the part of ASEAN to develop strong economic ties with neighbouring economies. The FTA was clearly understood as an interregional agreement between CER and ASEAN, although its name does not make the link explicit.

The possibility of an FTA between CER and the ASEAN Free Trade Area (AFTA) was first formally raised on 1 October 1999 at the fourth ASEAN-CER Ministerial Meeting in Singapore. Not all ASEAN members were as enthusiastic about the possible link as Singapore, who set the meeting agenda, leading one commentator to note, "The ASEAN 'consensus' on this issue was fragile even before the task force was formed" (Okamoto 2010, 214, Note 5). Despite this hesitance on the part of some ASEAN members, a consensus was reached and ASEAN and CER Ministers commissioned a High-Level Task Force to determine the feasibility of such an agreement by 2010.

The High-Level Task Force was strongly endorsed by ASEAN and CER countries alike, with eminent persons from economic, business and political backgrounds included in the thirteen-strong group. The Task Force was chaired by former Philippine Prime Minister and Economic Minister, Mr. Cesar E. A. Virata. Australia's representative was the Hon. Tim Fisher - Member of Parliament and until late 1999 the Deputy Prime Minister - while Sir William Birch, Finance Minister until late 1999, represented New 
Zealand. ${ }^{7}$ The Task Force met three times during 2000 - on the $8^{\text {th }}$ to $9^{\text {th }}$ February at the ASEAN Secretariat in Jakarta; on $27^{\text {th }}$ to $28^{\text {th }}$ April in Queenstown, New Zealand, and on the $2^{\text {nd }}$ to $3^{\text {rd }}$ August in Siem Reap, Cambodia (High Level Task Force 2000b).

The resulting "Angkor Agenda", presented by Cesar Virata at the fifth AEM-CER Consultations in Chiang Mai, Thailand on 6 October 2000, supported forming an AFTACER FTA on both economic and political grounds. It concluded that "establishing a free trade area between AFTA and CER [was] not only feasible but also advisable if both ASEAN and CER [were] at least to keep pace with the rapidly changing world of today" (High Level Task Force 2000a, §2.1, emphasis in original). The Task Force cited economic imperatives for the FTA as well as political reasons. The FTA was expected to double the economic output of the combined Free Trade Area to a combined GDP of 1 trillion USD, to demonstrate the members' commitment to economic reform and make both regions more attractive locations for investment. The Australian lead negotiator on AANZFTA suggests that this last factor was particularly significant - ASEAN was concerned about ensuring high levels of Foreign Direct Investment (FDI) into the region (Mugliston 2011, interview). The FTA was also anticipated to strengthen the bargaining position of both ASEAN and CER vis-à-vis other actors in international relations (High Level Task Force 2000a). A former Secretary General of ASEAN suggests that this point referred particularly to the agricultural subsidies of the United States and the EU (Severino 2006, 318). The Task Force further recommended that liberalisation take

\footnotetext{
${ }^{7}$ The full list of members included: Mr Cesar Virata as Chairman of the Task Force; Mr Ahmad Isa from Brunei Darussalam; Mr Kong Vibol from Cambodia; Mr Tunky Ariwibowo from Indonesia; Mr Somchitch Inthamith from Laos PDR; Dr Mohd. Haflah Piei from Malaysia; Mr Maung Maung Yi from Myanmar; Dr Cielito Habito from the Philippines; Dr Lee Tsao Yuan from Singapore; Dr Wisarn Pupphavesa from Thailand; Mr Hoang Tich Phuc from Vietnam; Hon. Tim Fisher from Australia; and Sir William Birch from New Zealand. (High Level Task Force 2000b)
} 
place within the AFTA-CER FTA at a pace no faster than within AFTA, but ahead of APEC (High Level Task Force 2000a).

The Angkor Agenda clearly distinguishes between CER and ASEAN as regional actors. The two are referred to as "regional groups", although they are also understood as part of a larger, more nebulous "region". Thus: "On the political side, the proposed FTA will strengthen the bargaining position of both regional groups as they negotiate both regionally and multilaterally in areas of common interest to them. It will send a strong signal to the rest of the world of the region's commitment to policy reform, enhancing its position of stability as a credible trade partner and host to foreign investments" (High Level Task Force 2000a, §3. Emphasis added). ${ }^{8}$ The Angkor Agenda also explicitly sees the proposed FTA in the context of 'new regionalism' and "a veritable explosion of regional integration arrangements (RIAs)" since 1990 (High Level Task Force 2000a, §1.5). Moreover, the Angkor Agenda proposes the AFTA-CER FTA (as it called it) explicitly in the context of interregionalism, described as "inter-bloc arrangements" (High Level Task Force 2000a, §1.6). It is clear that the High Level Task Force saw the AFTA-CER FTA as an explicitly inter-regional agreement between CER on the one hand and ASEAN on the other.

The day before AEM-CER Consultations, the FTA proposal ran aground however during the annual ASEAN Economic Ministers (AEM) Meeting held on the $5^{\text {th }}$ October 2000, in Chiang Mai, Thailand. In what the then ASEAN Secretary General Rodolfo Severino has described as "tense discussions among the ASEAN Ministers" (Severino 2006, 318), Rafidah Aziz, the Malaysian Minister for International Trade and Industry, raised objections to the FTA. Wise to the "political elements" of the proposed merger of AFTA

\footnotetext{
${ }^{8}$ Given ASEAN's supposed concern with promoting FDI at the turn of the millennium (Mugliston 2011, interview), it is possible that "the region" refers specifically to the former.
} 
and CER, Aziz noted that "the environment must be right first". AFTA, she noted, "is not a simply economic thing - it's political" (Kyodo News International Inc. 2000). This opposition spoke no doubt in part to the tensions between Malaysia and Australia (and particularly between their Prime Ministers Mahathir and Paul Keating) over differing visions for economic integration in the region and the balance between free trade and development (Higgot and Stubbs 1995; Capie 2011, 161).

Although Malaysian opposition had temporarily shelved the FTA, the High Level Task Force's report was well received, with Ministers agreeing on the importance of advancing the AFTA-CER linkage and taking action as set out in the Angkor Agenda (ASEAN and CER Ministers 2000). In order to maintain ASEAN-CER momentum and advance the goals laid out in the Angkor Agenda, the Ministers proposed the creation of a Comprehensive Economic Partnership (CEP) between ASEAN and CER (ASEAN and CER Ministers 2000). The CEP implemented a work programme aimed predominantly at capacity building. It covered skills and infrastructure assistance in newer ASEAN countries that would facilitate trade and investment; capacity building; trade and investment promotion including some liberalisation in the form of non-tariff barrier reduction; "new economy" work to make full use of information technology and ecommerce; and "other areas of cooperation" as identified through the AEM-CER process (ASEAN and CER 2000). The CEP was formally implemented when ASEAN and CER Ministers signed the Joint Ministerial Declaration on the AFTA-CER CEP on 14 September 2002 at the annual AEM-CER Consultations in Brunei Darussalam (ASEAN and CER Ministers 2002). According to Australia's lead negotiator on AANZFTA the CEP played an essential role in enabling cooperation between CER and ASEAN to continue despite the setback at the 2000 Consultations (Mugliston 2011, interview). From 2002 
to 2003 the bilateral trade between ASEAN and CER increased by 33\% from US $\$ 20.7$ billion to US $\$ 27.56$ billion. The work of the CEP was supported by the newly established AFTA-CER Business Council (ACBC) (ASEAN and CER Ministers 2004c).

Four years after the initial presentation of the Angkor Agenda, ASEAN Economic Ministers reached a consensus at their $37^{\text {th }}$ annual meeting held in Jakarta from 29 to 30 June 2004 to initiate FTA negotiations with Australia and New Zealand. This decision came in the context of a region-wide approach to trade agreements between ASEAN and its key strategic partners, including Japan, China and India (ASEAN Ministers of Foreign Affairs 2004). Mahathir's 2003 resignation as Malaysia's Prime Minister also removed a source of antagonism between the two regions that had prevented trade negotiations until then. As one commentator observes, the initial AFTA-CER dialogue was (at least publically) premised on the explicit grounds that it would not involve a Free Trade Area, making ASEAN's 1999 proposal to establish the Task Force "quite a turnaround" (Okamoto 2010, 213-214). The transition from the situation in 2000, when Malaysia had publically refused to support negotiations, to that of 2004 where members were eager to commence negotiations on an FTA that would "promote growth and development and increase living standards throughout the region" was also, in the words of the ASEAN Secretary General, “a dramatic turnaround” (Severino 2006, 320).

ASEAN's decision was welcomed at the 2004 AEM-CER Ministerial Consultations in Jakarta on 5 September 2004, and Ministers recommended to leaders that ASEAN, Australia and New Zealand proceed with negotiations of an FTA (ASEAN and CER Ministers 2004c). An ASEAN-Australia-New Zealand Commemorative Summit was convened as part of the annual ASEAN Summit taking place in Vientiane in November 2004 to mark thirty years of ASEAN-Australia and ASEAN-New Zealand relations. It was 
at this summit that Ministers officially agreed on the ASEAN-Australia-New Zealand Free Trade Agreement negotiations (ASEAN and CER Ministers 2004b), as well as a set of guiding principles for negotiations (ASEAN and CER Ministers 2004a).

Following approval, negotiations commenced formally in March 2005, conducted through an ASEAN-Australia and New Zealand Trade Negotiating Committee (AANZTNC). This consisted of lead negotiators from Australia, New Zealand and the ten ASEAN countries, and was supported by thematic working groups (Mugliston 2009). Negotiations were also conducted at the Ministerial level during the annual ASEAN-CER Ministerial Meetings. The meetings were co-chaired by Australia, New Zealand and Brunei Darussalam, representing ASEAN. They were explicitly interregional in format: on the one end of the table sat the Australian and New Zealand lead negotiators, with their negotiating teams arrayed behind them. At the other end of the table sat the ASEAN lead negotiators, arranged in a horse-shoe formation with the representative from Brunei Darussalam at the centre. These negotiations were conducted in plenary, although prior to the negotiations, ASEAN members as well as Australia and New Zealand negotiators reached agreement on a group basis on issues to be discussed. In support of the plenary sessions, the thematic working groups negotiated the technical aspects of the agreement, according to the negotiating position announced by the lead negotiator. These groups then reported back to the plenary session. Towards the end of negotiations, these reports were up to twice a day (New Zealand Official 2011, interview).

The physical layout of the negotiations is significant; in placing ASEAN at one end of the table and CER at the other, the explicit group-to-group character of the negotiations was reinforced. Although the final name of the agreement did not follow the interregional 
"AFTA-CER FTA" described in the Angkor Agenda, it is apparent that in everything but name, AANZFTA is an interregional agreement. Indeed, the name change was merely in recognition that neither AFTA nor CER are customs unions. In other words, calling the agreement the "AFTA-CER FTA" would have implied establishing a single external tariff for AFTA and CER (Severino 2006, 320).

AANZFTA was finalised at the annual ASEAN-CER Ministerial Meeting in August 2008. The ASEAN states were anxious to complete the agreement because of the resources involved; Mugliston recalls, “you get the sense that if you didn't do it then, there was the risk you would just lose it for a while" (Mugliston 2011, interview). A New Zealand official interviewed for this research suggests that the failure to reach agreement on the Doha Development Round of the WTO talks held in Geneva on 21-30 July 2008 provided further motivation to conclude (New Zealand Official 2011, interview).

After four years and sixteen negotiating rounds, the substantive completion of FTA negotiations was announced on 28 August 2008 in Singapore and officially signed on 27 February 2009 (ASEAN and CER Ministers 2009). ${ }^{9}$ The agreement entered into force for most parties on 1 January, 2010, although a phased entry was negotiated for Laos and Cambodia on 1 January, 2011. Indonesia, the final party, completed the internal requirements enabling implementation during 2011.

For Australia and New Zealand, the agreement had direct economic benefits, but these paled in comparison with the broader strategic advantages of concluding an FTA with ASEAN - the regional organisation at the centre of debates about Asian regional

\footnotetext{
9 Although after this point, on-going bilateral negotiations between Australia, Indonesia, Malaysia and Thailand took place regarding automotive industry access.
} 
integration. Mugliston recalls his concern that the agreement succeed because of these implications:

For various reasons, we [Australia and New Zealand] were not part of the ASEAN+3 Chiang Mai Initiative. ${ }^{10}$ And basically I've always had that in my mind as I've worked with ASEAN on AANZFTA. The way I saw it, was that we may only have one shot at this. And if we don't nail it now, we may not get another opportunity for quite a while. At the same time, we had to be able to sell the outcome domestically. So what that meant is that we really had to push ASEAN, and we did (Mugliston 2011, interview).

Australia and New Zealand's use of FTAs to achieve strategic objectives was not unprecedented (Dent 2003), but it was the first time that they had done so jointly. The history of CER-ASEAN relations that developed in the 1990s was the obvious foundation for the AANZFTA negotiations, but on what basis did this cooperation initially emerge? What enabled trans-Tasman cooperation to spill over into external cooperation with ASEAN?

The remainder of this chapter demonstrates that formal Australian and New Zealand cooperation with ASEAN was made possible because of the existing trans-Tasman regulatory framework. This framework provided a flexible set of intergovernmental and supranational regional institutions that supported and indeed encouraged cooperation on AANZFTA. The following section discusses the role played by issue-specific transTasman institutions in establishing relations between CER and ASEAN in the mid-1990s.

\footnotetext{
10 The Chiang Mai Initiative was an ASEAN+3 based series of bilateral currency swap agreements that emerged in response to the East Asian Financial Crisis. In formalising financial cooperation between the ASEAN +3 group it contributed to the latter's centrality to the East Asian regional architecture, and remains relevant (Henning 2009).
} 


\subsection{Issue Specificity and the Adaptability of Trans-Tasman Institutions}

Official explanations for Australia-New Zealand cooperation on AANZFTA invariably refer to its genesis in the CER-ASEAN relations of the 1990s (Crean 2009; Mugliston 2009; Taylor 2011, interview). AANZFTA, indeed, emerged from this CER-ASEAN link, so the question then becomes, why did Australia and New Zealand cooperate with ASEAN during the 1990s? As Chapter Three documents, some impetus for trans-Tasman cooperation over ASEAN existed in the 1970s, but the trans-Tasman relationship lacked the structure and narrative that might have supported formal Australia-New Zealand cooperation on ASEAN at this stage. What made CER-ASEAN interregionalism possible?

This section demonstrates the importance of the institutional structure of trans-Tasman integration in enabling CER-ASEAN relations in the 1990s. Trans-Tasman institutions presented Australian and New Zealand officials with a framework within which to develop a CER-ASEAN relationship, when prompted by ASEAN. In particular, the issuespecific nature of these institutions meant that spillover occurred in particular issue areas; cooperation developed rapidly and in depth in those areas that were supported by pre-existing trans-Tasman institutions. This suggests that these institutions were issue-specific but not context-specific. Trans-Tasman institutions, once established, have proven relatively easy to translate to new functional contexts. This section also shows how actors within these institutions began to exert their preferences and become protagonists of CER-ASEAN interregionalism, although this aspect of the relationship becomes more fully apparent in the following section. 
The genesis of CER-ASEAN interregionalism

The initial momentum for CER-ASEAN relations came from ASEAN. Specifically, at the (Australian) National Trade and Investment Outlook Conference held in Melbourne on 24-26 November 1993, the Deputy Thai Prime Minister Mr Supachai proposed closer links between the newly formed AFTA and the more established CER. Shortly thereafter, DFAT's East Asia Analytical Unit released a report, which urged the government to "consider establishing a formal dialogue between CER and AFTA", noting "a number of significant parallels between the two institutions, although CER has a longer history and is at a more advanced stage of development" (East Asia Economic Analytical Unit 1994, Executive Summary). The $16^{\text {th }}$ ASEAN-Australia Forum held in Canberra on 3-4 May 1994 supported this proposal. A joint press release issued at the Forum noted that the links “merited further discussion" (ASEAN-Australia Forum 1994).

The following year, this came to pass when in September 1995 Australian and New Zealand Ministers were invited to attend an inaugural AFTA-CER Ministerial Meeting. This meeting did not seek to achieve trade liberalisation. Rather, the meeting was seen primarily as an opportunity to share information and experiences between AFTA and CER. A joint press statement on the meeting noted that Ministers from both regions "reaffirmed their commitment to the multilateral trading system and the need for both regional trading arrangements to reinforce the process of liberalisation within the WTO framework" (ASEAN and CER Ministers 1995, §3). In light of their commitment to the liberal global economic order, the meeting was specifically couched in notions of open regionalism: "the Minsters agreed to establish region-to-region linkages between the free trade areas, reflecting the 'open regionalism' concept of AFTA and the CER" (ASEAN and CER Ministers 1995, §3). 
The meeting highlighted seven areas of cooperation between the two FTAs. These were: "exchange of information, human resource development, customs matters, standards and conformance, trade and investment facilitation and promotion, competition policy and industrial cooperation" (ASEAN and CER Ministers 1995, §3). Among these seven areas, four specific goals were outlined for completion within 12 months, namely the creation of an AFTA CER Customs Compendium; the linkage of Trade and Investment Databases; exchange of Information on Standards and Conformance and collaborative work on ISO 14000 Environmental Certifications; and information promotion on standards by featuring developments in CER standards and conformance in the ASEAN standards and Quality Bulletin (ASEAN and CER Ministers 1995, §6).

\section{Issue-specific trans-Tasman institutions as a framework for cooperation}

The initial push for integration came at the governmental level, but from this point forward the centrality of trans-Tasman institutional framework in enabling the interregional relationship is readily apparent. Following the inaugural CER-ASEAN Ministerial Meeting, in late 1995 the ASEAN Consultative Committee on Standards and Quality (ACCSQ) ${ }^{11}$ invited their CER counterparts to a high-level meeting to take place on 17 January, 1996 in Brunei. Despite the short notice of the invitation, high-level participation was secured for the meeting, reflecting the enthusiasm of CER representatives to establish this connection with ACCSQ. An internal New Zealand Ministry of Foreign Affairs communication notes the enthusiasm of the Executive Director of JAS-ANZ, who was "keen that JAS-ANZ take part and develop its links with ASEAN counterparts" (Ministry of Foreign Affairs and Trade 1995, §11).

\footnotetext{
${ }^{11}$ The ACCSQ consists of the Chief Executives of the respective standard setting bodies of the ASEAN countries.
} 
The trans-Tasman contingent to the meeting numbered a total of eight representatives six Australians and two New Zealanders. They included Brian O'Neill of the Australian Environmental Protection Agency (EPA); Steve Keeling, Director of Operations of JASANZ; the Chief Executive of Standards Australia Stewart Horwood; John Gilmour, Chief Executive of the Australian National Association of Testing Authorities (NATA); as well as Neal Davis, who was Australian High Commissioner to Brunei, and John Buckley, an Assistant Secretary at DFAT (Davenport 1996b). The two New Zealanders were Peter Davenport, Chief Executive of Standards New Zealand, and Malcolm Bell from Telarc (a management systems certifier). Representation therefore included governmental actors as well as actors from within trans-Tasman institutions, an indication that the CERASEAN relationship was beginning to broaden its constituency.

According to a report by Peter Davenport, the meeting was a success, and there was general agreement on all sides to further the dialogue (Davenport 1996b). To that end, the delegates agreed to complete a Memorandum of Understanding (MoU) that would cover the agreed list of joint AFTA-CER standard-setting activities. There was some initial caution from the New Zealand Ministry of Commerce however. Graham Boxall of the Ministry's Business Policy Division was concerned that if the Memorandum were to be produced, it should be "designed to achieve a specific purpose and produce tangible projects which could be tracked over time" (Boxall 1996b).

Davenport was quick to reply, affirming that Standards Australia and Standards New Zealand were committed to ensuring that the MoU was a quality document so that the relationship between ACCSQ and the relevant CER bodies advanced smoothly. He noted, "I can assure you that SA and SNZ are keen to progress this and I would be surprised if the others weren't too" (Davenport 1996a). Steve Keeling of JAS-ANZ responded to 
Boxall on 4 March, noting that ASEAN would set the pace of the work, and that an MoU would provide a "more formal framework" within which to advance work with ASEAN, including the negotiation of bilateral and multilateral agreements (Keeling 1996).

The importance of existing trans-Tasman institutional cooperation in providing a platform for CER-ASEAN integration could not be made clearer than by ASEAN-Australia developments that took place around the same time. At the $17^{\text {th }}$ ASEAN-Australian Forum on 12-13 March, 1996, a paper prepared by Standards Australia and DFAT entitled "A Regional Path to International Building Standards" was presented. This document outlined possibilities for ASEAN-Australia cooperation on establishing building standards in the Asia-Pacific region. Significantly the document noted that: "given the cooperation between Australia and New Zealand in the Standards Area, development between ASEAN and Australian developments [sic] can be transferred to AFTA-CER cooperation at a later date" (Department of Foreign Affairs and Trade and Standards Australia 1996).

Pre-existing trans-Tasman cooperation in standard setting had created institutions that were able to be employed to achieve pre-defined goals. In the context of creating regionwide building standards in the Asia-Pacific, trans-Tasman institutions provided a potential force-multiplier, by spreading the use of particular standards within the region. Because of the precedent of trans-Tasman cooperation in standard setting, it was an apparently logical step from ASEAN-Australia cooperation to ASEAN-CER cooperation. This proposal did not come in the context of CER-ASEAN relations, but at the ASEAN-Australia Forum - in which New Zealand had no formal part. Trans-Tasman institutional structures in this particular issue-area were available and provided a platform for the goals of actors within standard-setting institutions. 
The issue-specific character of trans-Tasman institutionalisation meant therefore that spillover was channelled to specific issue areas in which institutional competence already existed. In the area of standard setting, existing trans-Tasman institutions provided a precedent for Australia and New Zealand to cooperate in those issue areas. These institutions also provided a framework within which this cooperation might be extended beyond the trans-Tasman context. After ASEAN's proposal for CER-ASEAN cooperation in these specific issue-areas, only a limited conceptual and organisational transition was required to adapt these institutions to the interregional level because of the existing trans-Tasman framework. Moreover, a mentality of Australia-New Zealand cooperation within Australasian standard-setting bodies clearly pervaded the institutions that functioned in the trans-Tasman environment.

This section has therefore demonstrated that the decentralised, issue-specific nature of trans-Tasman institutions is important in understanding why, how and in which issue areas joint Australia-New Zealand cooperation with ASEAN emerged. An expansion from Australia-ASEAN to CER-ASEAN cooperation in these particular issue areas was a logical and apparently natural evolution. A trans-Tasman institutional environment in these specific issue areas enabled trans-Tasman actors to advance cooperation with ASEAN on a regional, not a national, basis. This raises an important question, however: Who was driving this cooperation? Did trans-Tasman institutions, following a state-centric interpretation, simply provide a framework through which respective Australian and New Zealand officials could cooperate to pursue set strategic interests? Or, following a neo-functionalist perspective did trans-Tasman institutions in fact shape and align the preferences and world views of their members and the officials with whom they interacted? The following section explores the process of deepening and broadening 
CER-ASEAN relations. There is evidence to support both the state-centric and neofunctional contentions outlined above. Resolving this debate is beyond the scope of this thesis, but this analysis suggests that the latter provides a more credible interpretation of the CER-ASEAN process. Australian and New Zealand Ministry officials maintained ownership over many aspects of the interregional relationship. These officials' preferences and world-views were however modified through interactions with one another and with other regional actors such as non-government officials from within the trans-Tasman institutional environment.

\subsection{Deepening and Broadening Interregional Integration}

How did CER-ASEAN relations deepen within issue-areas and broaden to include others? Who was driving this process? This section documents the evolution of CER-ASEAN relations. It does not resolve the inter-governmental/neo-functional debate, but it provides evidence that suggests that the inclusion of trans-Tasman institutions in the CER-ASEAN relationship, while perhaps pragmatically motivated by officials' goals of interregional cooperation, meant that actors within trans-Tasman institutions became drivers of interregional integration.

The initial inclusion of JAS-ANZ and other trans-Tasman standard-setting bodies in the relationship with ACCSQ contributed to the creation of multiple sites of inter-regional governance by institutionalising relations between non-governmental regional actors. These actors quickly became protagonists in the CER-ASEAN relationship in their own right, and began to assert their own preferences. Standard New Zealand's Peter Davenport, for instance, had a vision for the evolution of CER-ASEAN relations that went hand in hand with greater trans-Tasman integration. He favoured the creation of a CER counterpart to ACCSQ rather than signing a MoU between existing parties, noting: 
The reason why we needed an MoU is that we have no formal Standards and Conformance infrastructure comparable with ASEAN's ACCSQ. To enable progress to be made, we need a CER "Body" called the ANZCCSQ. I believe it would be inappropriate to have an MoU with individual organizations within CER but I suppose that is not impossible. In that case JAS-ANZ, SA, SNZ, NATA, TELARC [sic] and the CRI's (measurement) would all need to be signatories (Davenport 1996a).

According to Davenport, the Australian government was willing for there to be an advisory council for Standards and Conformance that would report to the relevant minister. To this end, he notes that at a Standards Australia and Standards New Zealand Joint Technical Management Group (SA/SNZs JTMG) meeting in Sydney on Friday 1 March, the matter of approaching the ACCSQ and requesting information on their organisational model was scheduled to be raised. The JTMG intended to "promote the adoption of internationally based Standards along the Joint AS/NZS model" (Davenport 1996a).

The activism of Davenport to further develop the institutional framework of transTasman standard setting suggests that in addition to prior trans-Tasman integration acting as a platform for CER-ASEAN relations, actors within trans-Tasman institutions also contributed to CER-ASEAN interregionalism. They brought their own set of preferences, ideas and identities as trans-Tasman actors to the relationship. Davenport's proposal for a new Australia-New Zealand institution also demonstrates that interregionalism with ASEAN encouraged further trans-Tasman integration. ASEAN does not appear to have actively promoted the creation of any CER counterpart to ACCSQ; rather it appears that the ACCSQ provided a model for standards and conformity that CER actors (notably Peter Davenport) wished to emulate. This suggests that transTasman integration is a dynamic process driven not only by officials in both countries, 
but also by stakeholders in the existing trans-Tasman structure. Moreover, the establishment of inter-institutional interregional links allowed for the diffusion of ideas (Börzel and Risse 2009, 6-9) and the modification of actor preferences. Regionalism and interregionalism seem therefore to be complementary processes.

It is unclear from archival evidence why Davenport's proposal for an "ANZCCSQ" did not go ahead. It is possible that JAS-ANZ already provided an effective over-arching framework for conformity and assessment and therefore a new body would simply have been an unnecessary development. Perhaps also, such an institution would have been antithetical to the non-bureaucratic approach to regulation taken by Australia and New Zealand (Lloyd 1995, 271). Another possibility is of course that state actors decided that such a development may have transferred authority that they were unwilling to relinquish. This would tend to support an inter-governmentalist interpretation of transTasman integration and CER-ASEAN relations. Further primary source evidence would be required to conclusively determine the matter.

In the event, the New Zealand Ministry of Commerce took the drafting of the MoU in hand in recognition of the proposed document's merit and the necessity of it being produced to a high standard. The Ministry's Graham Boxall wrote to JAS-ANZ, Standards New Zealand, TELARC and the Measurement Standards Laboratory confirming New Zealand's enthusiasm for the MoU on AFTA-CER standard setting cooperation and that New Zealand (i.e. the Ministry of Commerce) was willing to take the lead on drafting the document. Boxall noted, "It is a key focus of New Zealand, in developing the AFTA/CER relationship, to forge links at the technical level to enable both sides to identify areas of cooperation, and from that, develop projects which are of tangible benefit to the 
technical bodies concerned in both ASEAN and CER. The MOU could provide that focus" (Boxall 1996a)

While the MoU was in development, a further AFTA-CER Senior Economic Officials Meeting (SEOM) took place on 4 June in Kuala Lumpur to review the four short-term goals of the first meeting noted above. A fax from Wellington to MFAT posts in the ASEAN countries indicates that this meeting took place against a backdrop of "increased high level bilateral contacts between CER and ASEAN countries" (Ministry of Foreign Affairs and Trade 1996, §5). This meeting aimed to review progress towards completion of pre-defined goals, but Australian and New Zealand officials clearly saw the potential for deepening and broadening the relationship in the future. The same MFAT communication notes, "As DFAT pointed out to us privately, an umbrella MOU on AFTA/CER cooperation might have the unintended disadvantage of limiting the dialogue egg [sic] if it confined it to facilitation initiatives only - a valid point)" (Ministry of Foreign Affairs and Trade 1996, §9). This communication is interesting as it suggests that Australian and New Zealand governments were willing to relinquish control over the pace and direction of CER-ASEAN integration, allowing the process to deepen within established issue areas, and broaden to incorporate new issue areas.

The same MFAT report gives some indication of how Australia and New Zealand envisaged this process taking place. It notes that there was general agreement that there was a need to take the relationship step by step and complete items on the agreed priority list. At the same time, there was some initial talk of trade liberalisation. The Malaysian delegation for instance was reported as "noting that there was a 'natural tendency' for ASEAN and CER to come together beyond a facilitation agenda, but there was 'no linkage at the moment in the trade liberalisation sense"' (Ministry of Foreign 
Affairs and Trade 1996, §16). MFAT however was clear that a definite proposal at that point for a "liberalisation agenda by the CER countries could be counterproductive - and risk drawing a firm negative reaction from some of the key ASEANs" (Ministry of Foreign Affairs and Trade 1996, §18). What was required, according to MFAT, was "further preparatory work, including research work and broadening the constituency for AFTA/CER linkages through the involvement of the business sector... and desirably, the idea [for a liberalisation agenda] should emerge first from the ASEAN side" (Ministry of Foreign Affairs and Trade 1996, §18).

Trade liberalisation was an outcome of CER-ASEAN interregionalism that was clearly anticipated by all parties, even if it was recognised that the relationship was not yet mature enough to support it. Before this could happen, the relationship needed to be deepened by intensifying existing work, and broadened through inclusion of other actors such as the business sector. This communication demonstrates that ministerial officials maintained an important role in driving the ASEAN-CER relationship forward. It was Ministry officials who proposed co-opting the support of the business sector to advance their own goals, rather than the other way around. As documentary evidence about the 1988 Services Review of CER reveals, this is consistent with the way integration took place between Australia and New Zealand (Leslie and Elijah 2011, 10). The same pattern of engagement that drove regional integration between Australia and New Zealand is therefore also evident in the CER-ASEAN relationship. It might be tempting to interpret this vision for the relationship through a purely intergovernmental lens. This thesis suggests however that it represents part of the spectrum of the deepening and broadening CER-ASEAN relationship, which functioned at multiple levels 
including at the trans- and supranational level in particular issue areas like, as detailed above, standard setting.

As a corollary of deepening and broadening CER-ASEAN interregionalism, there was also a real increase in relations between Australia and New Zealand. Foreshadowing the trans-Tasman consultations that would be essential during AANZFTA negotiations a decade later (Mugliston 2011, interview), Ministry and other officials met to determine the CER standpoint on various issues. For the MoU on standards cooperation, this took the form of a meeting on 13 June at the New Zealand Ministry of Commerce, reflecting that "Officials on both sides of the Tasman agree[d] the importance [sic] of a formal consultation between the two countries to progress [the] issues in a constructive way" (Boxall 1996a). The Australian invitees included representatives from CSIRO, NATA, the (Australian) National Standards Commission (NSC), Standards Australia, DIST, and DFAT; while the New Zealand institutions included Standards New Zealand, TELARC, Industrial Research Ltd, the Trade Measurement Unit (TMU), and MFAT. Naturally, JASANZ was also present. This meeting prepared a draft of the MoU, in advance of the second CER-ACCSQ meeting on 22 July 1996.

This sort of intensified engagement between ASEAN and CER and between Australia and New Zealand continued throughout the 1990s. An ASEAN/CER Officials Meeting then took place in mid-August in the Philippines, followed by the Second official ASEAN-CER Ministerial Meeting, from 12-13 September 1996 in Jakarta (ASEAN and CER Ministers 1996). ACCSQ-CER meetings continued on an annual basis, and an AFTA-CER Business Council (ACBC) was created to support the Closer Economic Partnership agreement introduced in 2002. 
During the first year of formal CER-ASEAN relations, linkages between the two groups were therefore established at a number of levels. These included at the formal (Foreign) Ministerial level, the senior economic official level, and the level of senior officials in intergovernmental and supranational institutions (standard setting and conformance), with further linkages envisaged to include the business community. These linkages were forged through a number of mechanisms, often at the suggestion of ASEAN. Ministerial contact was initially proposed by an ASEAN member, as were links between ACCSQ and the CER bodies. Other links resulted out of a need for continuity and on-going maintenance of the relationship (such as links at the senior economic officials level), while still others, such as between the business communities in both regions, were envisaged by as a way of "broadening the constituency" of inter-regional relations in preparation for later liberalisation (Ministry of Foreign Affairs and Trade 1996). The agenda for CER-ASEAN cooperation spilled over to new issue areas to support the work being done in existing areas and lay the foundations for envisaged trade liberalisation. ASEAN played an important role in initiating this agenda, and it was driven on the transTasman side by Australian and New Zealand government officials as well as actors in trans-Tasman institutions.

Above all, collaboration between the two regional organisations was highly functional, consistent with the approach taken to trans-Tasman integration. The manner in which progress in these areas was made also demonstrates the essential role of pre-existing regional institutions in CER as well as ASEAN. Pre-existing integration enabled Australia and New Zealand to establish joint cooperative efforts with ASEAN, and cooperation in turn encouraged greater integration between Australia and New Zealand. Pre-existing institutions played more than a passive role however. The operational scope and context 
of trans-Tasman institutions shaped the preferences of their members, who actively contributed to the interregional relationship by participating in important decisionmaking meetings between Australia and New Zealand and in promoting their preferences for regional institutionalisation. CER-ASEAN interregionalism was enabled by the existing regional integration within both organisations, and it is clear that the two processes were mutually reinforcing. The work on standard-setting between CER and ASEAN encapsulates the process of deepening cooperation. This cooperation ultimately enabled ASEAN-Australia-New Zealand FTA negotiations by creating inter-regional networks and institutions that supported and actively furthered an increase in relations. Spillover was driven by the demand for further cooperation in issue areas that would support existing work, and by the demand for institutions that could function in an interregional context.

\subsection{Conclusion}

In 1993, Thailand suggested that Australia, New Zealand and ASEAN should investigate links between CER and AFTA, a proposal that was readily taken up in Canberra and Wellington based on the perceived benefit of closer relations with ASEAN. The resulting CER-ASEAN interregionalism recognised both parties as distinct regional groups, providing an essential foundation for later CER-ASEAN trade liberalisation, although this was not originally an explicit goal of the relationship. Instead, CER-ASEAN relations evolved towards this aim over several years of cooperation. It was enabled and indeed encouraged by an existing trans-Tasman institutional environment, which set a precedent for Australia-New Zealand cooperation in specific issue areas and provided a framework to advance cooperation in these areas, including through the participation of relevant trans-Tasman institutional actors. The resulting multi-level interregionalism 
extended beyond the Ministerial level to include working officials and representatives from intergovernmental and supranational organisations, as well as the private sector (through the AFTA-CER Business Council).

A number of conclusions about the dynamics of trans-Tasman and CER-ASEAN integration can be drawn from this assessment. Firstly, the de-centralised nature of trans-Tasman institutionalisation and the attendant issue-specificity of institutions were important in establishing a precedent for trans-Tasman cooperation in those issueareas. This cooperation was able to be translated to a new (interregional) context, and relevant institutions were flexible enough to adapt to this new context.

Secondly, institutions shaped actor preferences. It became logical to employ transTasman capabilities to achieve wider goals, and there was some evidence that actors within trans-Tasman institutions developed a preference for greater institutionalisation at the trans-Tasman level. Spillover was driven by the demand for institutions that could operate in the CER-ASEAN context, which would support a growing work programme and ultimate vision of trade liberalisation.

Thirdly, interregionalism and regional integration were mutually reinforcing, dynamic processes. Greater CER-ASEAN cooperation required, and resulted in, greater transTasman cooperation. Again, this was evident on an issue-specific basis, rather than being exhibited at a general level. From this one can deduce a path dependency to transTasman spillover whereby previous cooperation in particular issue areas enabled later cooperation in those, or related, areas. The potential for Australia-New Zealand cooperation in these particular issue-areas seems to be an unintended consequence of the institutional capacities developed during the process of trans-Tasman integration. 
CER-ASEAN integration was therefore the result of a particular confluence of factors. ASEAN's encouragement that Australia and New Zealand cooperate as CER; a history of trans-Tasman cooperation in relevant issue-areas; the willingness of Australian and New Zealand officials to cooperate with one another to achieve goals; the availability of trans-Tasman institutions to adapt or be adapted to a new functional context and the existence of institutional actors who could drive interregional integration forward in particular issue areas; all contributed to spillover from internal trans-Tasman cooperation to external CER-ASEAN cooperation. This confluence of factors and especially the issue-specific nature of trans-Tasman institutional capabilities suggest that such spillover might not readily take place in other cases.

The following chapter tests the validity of this assumption through an examination of Australia and New Zealand's separate applications to the Asia-Europe Meeting (ASEM) process. It asks: why did Australia and New Zealand not cooperate on ASEM? What does this reflect about the trans-Tasman relationship and the basis on which joint AustraliaNew Zealand activity in international relations might take place? 


\section{Five}

\section{The Asia-Europe Meeting (ASEM)}

"Today people want to be part of the game. They want to be sitting at the table, whatever the topic discussed could be. It's a question of status, it's a question of knowledge, it's a question of being there and not being excluded by what can happen between the others." - Dominique Girard, Former Executive Director of the AsiaEurope Foundation (2011, interview)

\section{Introduction}

Australia and New Zealand both formally received a seat at the ASEM's top table at the ASEM 8 Summit held in Brussels October 2010. Joining ASEM was not, however, a transTasman endeavour. Indeed, Kevin Rudd's 2008 announcement that Australia intended to join the process came as a surprise to New Zealand. It was only after a year of internal discussion that New Zealand also submitted a formal application. Why did joint Australia-New Zealand cooperation emerge in the CER-ASEAN context and not in the ASEM context? What distinguishes the two cases?

This chapter examines Australia and New Zealand's applications to ASEM. Their applications reflect many of the dynamics evident in trans-Tasman integration and in CER-ASEAN relations. Both states proved susceptible to international and regional developments that threatened economic or political exclusion from key decision-making groups. A lack of available trans-Tasman institutions and actors to facilitate a cooperative agenda between Australia and New Zealand meant however that cooperation on ASEM was not an obvious policy option. Indeed, the political costs of cooperation may have outweighed any benefit of formal cooperation. Independent applications should not be considered an anomalous phenomenon, rather, they indicate 
the inherently apolitical and functional nature of trans-Tasman integration, which consists of a governance space (and attendant proliferation of institutions and actors) that operates principally at the Ministerial and officials level. As a high-level summit process, ASEM did not fit within the institutional and normative frameworks developed through the process of trans-Tasman integration.

This chapter proceeds in four main sections. The first provides an overview of ASEM. This section contextualises Australian and New Zealand interest in ASEM within the debates about contending models of Asian regionalism. Australia made initial, unsuccessful efforts to join ASEM during its early years, while after a cost-benefit analysis New Zealand decided not to seek membership at this time.

The second section documents the application process of Australia, which was initiated in 2008. Australian membership was motivated by a fear of exclusion from a multilateral forum that appeared to be gaining in influence, and should be interpreted in the context of the emphasis that newly-appointed Prime Minister Kevin Rudd placed on Australia's foreign policy and role in multilateral organisations.

A third section turns to the New Zealand application. For Wellington, the Australian membership application changed the cost-benefit calculation. Although ASEM membership involved resource implications, it was decided that remaining outside of ASEM would have harmed New Zealand's credibility as a legitimate partner in the AsiaPacific. It was decided accordingly to apply.

The fourth section discusses non-cooperation between Australia and New Zealand within the context of trans-Tasman integration and Australia and New Zealand's strategic approach to involvement in the Asia-Pacific region. ASEM was an issue outside 
of the scope of trans-Tasman integration; there was no history of trans-Tasman cooperation on ASEM and no formal trans-Tasman mechanism or institution through which cooperation on ASEM could be understood, and a response articulated. Moreover, the attraction of ASEM was for both Australia and New Zealand a seat at a high profile table with prominent world leaders, so ASEM was above the lower-level (ministerial and official) governance space that forms the primary foundation of trans-Tasman relations. For political reasons, the costs of applying jointly to ASEM would have been beyond any immediate benefit, even if such joint action had been considered.

\subsection{Background: ASEM and Contending Visions for Asian Regionalism}

Australia and New Zealand's application to the Asia-Europe Meeting should be considered in the context of the history of ASEM as an inter-regional forum, as well as the changing nature of Australia and New Zealand's engagement with Asia and Europe. ASEM emerged in the period of globalisation and the post-Cold War redistribution of global economic power during the 1990s. The collapse of the Soviet Union and the thawing of East-West relations heralded the disestablishment of bipolarity and the emergence of multiple nodes of concentrated economic activity. In particular, the dynamism and growth potential of emergent Asian economies led commentators to suggest a "triad" of economically prosperous regions - North America, Europe and (East) Asia (Ohmae 1985). At the same time, the end of the Cold War and the globalisation of the 1990s signalled a change in the type of struggle between countries and regions. Where Cold War conflict was political and ideological, tensions in the 1990s were based around economic imperatives. One commentator suggests that by the 1990s the triad had come to "dominate the world economic system" and that this "marked a 
relative global shift from geopolitics to geoeconomics, and from communist-capitalist bipolarity to inter-capitalist tripolarity" (Dent 2004, 214).

In this context emerged competing visions for the trajectory that regionalism in Asia would or should take. In the mid-1990s these centred principally on two models - the Asia Pacific Economic Cooperation (APEC) framework and ASEAN-based models, principally Mahathir's East Asian Economic Grouping (EAEG), based on the ASEAN+3 model (Higgot and Stubbs 1995). ASEM was in many ways a product of competing visions for Asian regionalism, rooted in conceptions of the triadic structure of the global economy.

An increase of US involvement and interest in the Asia Pacific Economic Cooperation (APEC) initiative in 1993 and 1994 had resulted in plans for a trans-Pacific free trade and investment zone, while the trans-Atlantic relationship had been strengthened at the same time under the New Transatlantic Agenda (NTA). This left a perceived "weak link" in the triadic system between Asia and Europe (Dent 2004, 214-215; Hänggi 1999). In 1994, the European Commission (EC) published a communication to the European Council entitled Towards a New Asia Strategy, which recognised that "the rise of Asia is dramatically changing the world balance of economic power" and that the EU "needs as a matter of urgency to strengthen its economic presence in Asia in order to maintain its leading role in the world economy" (European Commission 1994, 1).

In November 1994, a Franco-Singaporean proposal to establish an Asia-Europe Meeting was advanced. The initiative was spearheaded by the Singapore Prime Minister Goh Chok Tong. Goh first proposed this idea in a meeting with the French Prime Minister Edouard Balladur and further developed it at a meeting of the Institut Français des Relations Internationales (IFRI), suggesting a regular series of meetings between 
European and Asian leaders along the lines of the Asia-Pacific Economic Cooperation (APEC) Forum (Teo 2006). Goh's conception was for a dialogue framework between the EU and the ASEAN+3 grouping. ${ }^{12}$ Although many European powers had colonial ties with Asian states, contemporary Asia-Europe relations needed strengthening, to balance growing trans-Pacific and historically strong trans-Atlantic ties. The proposed AsiaEurope Meeting would therefore "bridge" the "missing link" in the relationships within the triad (Hänggi 1999). Asian states also had reason to engage with Europe. For East Asian states, a strengthened relationship with Europe would balance the influence of the regional powers like the United States, China, Japan and Russia (Dent 2004, 215). It also served to diversify the region's economic relations in an increasingly globalised world, including through access to the European market (Dent 2004).

The proposal was accepted and the inaugural Asia-Europe Meeting Summit (ASEM 1) was held in Bangkok on 1-2 March 1996. Fifteen Member States of the EU joined the ten states included in the ASEAN+3 grouping. At the Bangkok Summit, leaders from the 25 member countries agreed on the importance of promoting political, economic and cultural links between the two regions, and established an agenda for future engagement that included a Foreign Ministers' Meeting and an Economic Ministers' Meeting to be held in 1997. The agenda also included an informal Senior Officials Meeting (SOM) in Brussels in July 1996 that aimed to discuss economic cooperation initiatives between the two regions, including liberalisation and facilitation of trade and investments in accordance with the WTO agenda. Business and private sector links were envisaged through an Asia-Europe Business Forum (AEBF), whose inaugural meeting was scheduled to take place in France during 1996. It was also at this point that the Asia-

\footnotetext{
12 At the time of Goh's proposal, the seven ASEAN states were Brunei Darussalam, Indonesia, Malaysia, Philippines, Singapore, Thailand and Vietnam.
} 
Europe Foundation (ASEF) was conceived. ASEM's only permanent institution, ASEF promotes civil society connections between Asia and Europe, through a work programme that involves people-to-people, cultural, and intellectual exchanges between Asia and Europe. In addition, the Summit considered a number of possible Asia-Europe initiatives including a Finance Ministers' Meeting and an Asia-Europe Cooperation Framework (AECF) to establish the guidelines for the ASEM process (ASEM 1996). ${ }^{13}$ Figure 3 illustrates ASEM's institutional structure.

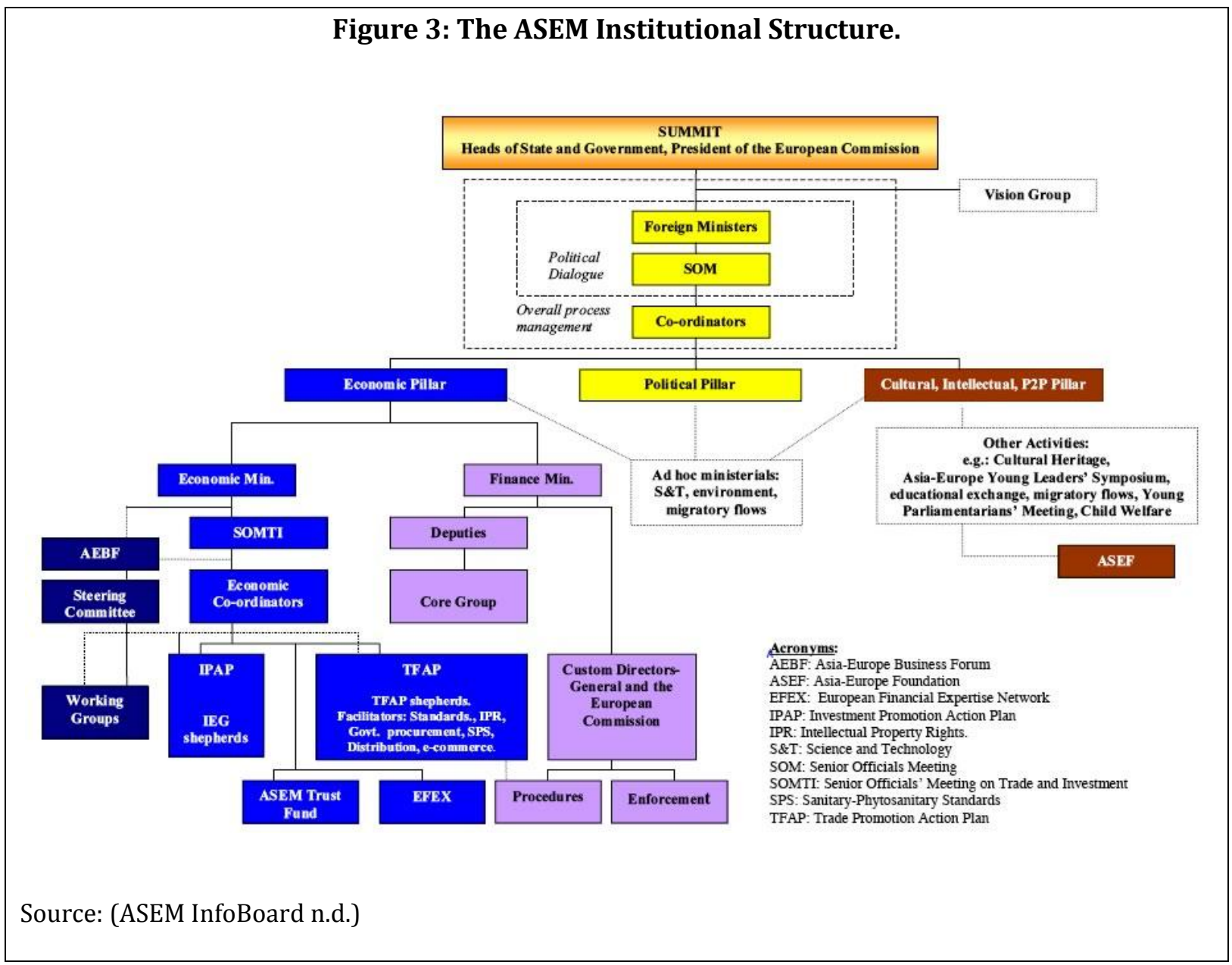

Australia clearly saw ASEM membership of strategic importance, and lobbied for ASEM membership in the lead-up to the inaugural 1996 Summit. Singaporean officials during 1995 had apparently indicated that it was likely Australia would be able to join ASEM as

\footnotetext{
${ }^{13}$ A Finance Ministers' Meeting (FMM) now takes place annually, as institutionalised in the AECF (ASEM $2000, \S 28$ ). The AECF was ultimately produced in 1998 and re-released in 2000 (ASEM 2000).
} 
a founding member, with the UK, Japan and Indonesia also supporting Australia (Capie 2011, 161). By the $5^{\text {th }}$ ASEAN Summit on 14-15 December 1995, the membership of ASEM had apparently been determined however, and it did not include Australia. Instead, it would be an "historic meeting of the Heads of State and Government of ten Asian nations [i.e. ASEAN+3] and fifteen European nations and the President of the European Commission" (ASEAN Heads of State and Government 1995).

ASEM's membership expanded twice before Australia and New Zealand joined along with Russia in 2010, both coincidental with EU enlargement. The first expansion took place at the ASEM 5 Summit in Hanoi on 8-9 October, 2004. The European enlargement to the EU-25 enabled three new ASEAN countries - Cambodia, Laos and Burma/Myanmar - to also join the process. ${ }^{14}$ The second expansion at the 2008 ASEM 7 Summit saw the playing field levelled slightly for the outnumbered Asian states with India, Mongolia, Pakistan and the ASEAN secretariat joining on the Asian side, to balance Bulgaria and Romania's entry on the European side - again because of internal EU enlargement..$^{15}$

Why had Australia not been able to join during this time? The primary reason was the rocky bilateral relationship between Australia and several key Asian states, principally Malaysia under Mahathir's leadership (Capie 2011; Murray 2010). ${ }^{16}$ Mahathir's EAEG

\footnotetext{
${ }^{14}$ Burma/Myanmar's entry had posed a political problem - the EU had been opposed based on the regimes human rights violations. For the 2004 Summit it was decided that Burma/Myanmar would not send top-level representation to the summits, and in return all of the new additions to the EU and ASEAN would be allowed to join ASEM - although this left the membership rather heavy on the European side. 15 ASEM enlargement does not follow a strict code, which is part of the reason Australia's application had been contentious. The Asia-Europe Cooperation Framework (ASEM 2000) provides regulations for membership expansion - in apparent recognition that this is both desirable and inevitable (de Crombrugghe 2011,173) - but does not specify the composition of "Asia" or "Europe". Russia and Australia/New Zealand do not easily fall into either category, hence (de Crombrugghe 2011, 173) suggests that "there is only one rational conclusion to draw: in such cases, politics are in command on how to orient candidates wishing to join."

${ }^{16}$ Relations with Indonesia also became strained following the John Howard government's support of East Timor's 1999 referendum on independence from Indonesia (Richardson 2005, 352).
} 
proposal was a much more restrictive interpretation of 'Asia' than that espoused in the Asia-Pacific Economic Cooperation (APEC) forum championed by Australia and its ally the United States (Higgot and Stubbs 1995), and Mahathir perceived Australia as overly motivated by free trade, rather than development. Matters were compounded by the strained personal relationship between Mahathir and Australian Prime Minister Paul Keating due to conflict within APEC (Capie 2011, 161). Australian Senate Hansard records detail a hope Australian economic support ${ }^{17}$ of countries within the East Asian Economic Caucus (EAEC - a watered-down version of the EAEG) might convince Mahathir that Australia should have a place at ASEM meetings, but this was not to be (Joint Standing Committee on Foreign Affairs 1997). Canberra re-applied to the process at the ASEM 2 Summit in London, 1998, and was again rejected.

When ASEM first emerged, New Zealand carefully analysed the costs and benefits of membership, but clearly did not see the same strategic potential in the process as did Australia. Understood as a process to facilitate dialogue between Asia and Europe, ASEM did not hold much initial appeal. As one former senior MFAT official notes, "New Zealand had a very well developed dialogue and historical relationship with Europe, and neither Ministers nor officials saw great benefit to New Zealand in joining a body whose purpose was to make Asia and Europe more familiar with one another" (Browne 2011, interview). Similarly, the costs of remaining outside the process did not seem great. If Australia was not to be accepted into ASEM, it was considered unlikely that New Zealand had much chance. Tony Browne recalls, "We certainly didn't want to get into pushing a fight that we weren't sure to be able to win" (Browne 2011, interview). While there was no formal dialogue across the Tasman on ASEM membership, Browne notes that "there

\footnotetext{
17 This included an AU\$1.35bn currency swap with Thailand during the 1997-1998 East Asian Financial Crisis.
} 
was a comfort in the fact that the Australians weren't seeking to join and therefore there wasn't such a need for us to address the negative perceptions of New Zealand not being in" (Browne 2011, interview).

Australia and New Zealand's early interest (or lack thereof) in the process reveals important insights into the influences on Australian and New Zealand foreign policy decisions. Australia's interest in this process demonstrates a clear concern with establishing a definition of "Asia" that would allow them a position of strategic importance - or at least relevance. The potential negative outcome of Australia's exclusion from a forum involving powerful European and Asian states was enough to motivate Australia to seek entry into the process, despite the fact that ASEM's focus on dialogue between Asia and Europe was of questionable direct benefit to Australia. Indeed, one prominent commentator lamented that the "part of the world which is completely dominant in Australia's economic, immigration, tourism and education flows, and in political and cultural influence in Australia's regional habitat, was closed to Australia politically" (FitzGerald 1997, 2).

New Zealand's approach was much more pragmatic. There were strategic benefits to membership, but given Australia's exclusion, the cost-benefit calculation simply did not support applying. As (Capie 2011) points out, Australia has the most advanced military in the region, is the fourth largest economy in Asia, and sees itself as playing a dominant role in determining the shape of Asian regionalism. New Zealand is a small country with limited diplomatic resources that are distributed based on careful cost-benefit analyses. Moreover, although the two countries are distinct, their foreign relations clearly affect one another. As Tony Browne suggests, "Australia and New Zealand having good relations in the region makes it easier for both countries to participate in regional 
bodies" (Browne 2011). The antagonism between Australia and Malaysia undoubtedly prevented Australia from joining ASEM and New Zealand was unwilling - and potentially unable - to join without its larger partner.

Australia and New Zealand do not have identical approaches to the region. They do however share the goal of being constructive participants in regional bodies. Australia and New Zealand's official engagement with the newly formed ASEAN began in the early 1970s. Both countries have sought to be part of the regional architecture in the AsiaPacific. The two share membership in most of the different economic, political and security groupings in the Asia-Pacific, including APEC and a number of ASEAN-based initiatives like the ASEAN Regional Forum (ARF), the ASEAN Defence Ministers Meeting Plus $(\mathrm{ADMM}+)^{18}$, and the East Asia Summit (EAS), which brings together the ASEAN+6 grouping (ASEAN+3, as well as India, Australia and New Zealand).

It is with this strategic approach to engaging in Asia in mind that the following section examines Australia and New Zealand's separate applications to ASEM. What do they reveal about the impact of trans-Tasman relations on Australia and New Zealand's respective foreign policies? Why was there no cooperation on ASEM, and what does this indicate about the drivers of "spillover" from intra-regional economic integration to external cooperation with third parties?

\section{2 "Ambition" and a Seat at the Table: Australian Membership in ASEM}

After initial failed membership efforts, Australia did not actively seek to apply to ASEM for the next decade. Australia's approach to regional integration also changed. Under the conservative Liberal Party Prime Minister John Howard, Australia's foreign policy was

\footnotetext{
${ }^{18}$ The "Plus" refers to the non-ASEAN states involved in the process.
} 
characterised by increasingly close ties with the United States, presumably in an effort to further the APEC agenda. On-going Malaysian opposition to Australian ASEM membership meant that considerations for an Australian application were, at least temporarily, put to one side. On the other side of the Tasman the calculation over ASEM had not changed - it still did not make sense for New Zealand to try and seek membership without Australia. At best such a move would be a waste of resources that would amount to little strategic gain. At worst it would strain trans-Tasman relations unnecessarily. ASEM meanwhile excited little international attention and its members devoted limited diplomatic energy to its Summits; the Summit attendance of European members in particular remained low until 2008 (Heenan 2009, §52).

In 2008, the onset of the Global Financial Crisis changed ASEM's apparent utility. The ASEM 7 Summit was scheduled to meet in Beijing on the 24th to 25th October 2008 just as the extent of the Global Financial Crisis was being made apparent. The Summit came off the back of the $8^{\text {th }}$ ASEM Finance Ministers' Meeting (in Jeju, Korea in June 2008), at which leaders affirmed the need for coordinated policy response to the financial crisis, as well as cooperation between ASEM countries in such areas as economic integration, finance and infrastructure (ASEM 2008). The Beijing Summit also preceded the inaugural G-20 Summit held on 14-15 November 2008 in Washington, D.C., at which the recently elected Australian Prime Minister Rudd had ensured Australia would be represented at the G-20, and it became apparent that ASEM might contribute to setting the agenda for the meeting.

"Suddenly," Tony Browne recalls, "ASEM looked like it had the ability to contribute to real decisions rather than simply encouraging engagement. This led Kevin Rudd to decide that Australia should indeed join ASEM" (Browne 2011, interview). Quick to 
grasp the benefit of being included in such a forum as ASEM and alarmed at the prospect of exclusion, Rudd instructed DFAT to secure an invitation to ASEM. Rudd's announcement of Australia's ASEM intentions came in the context of a concerted effort at multilateralism on the part of the new Prime Minister. Rudd's vision for Australia included an active role at the centre of debates about Asian regionalism. Rudd notably called for an "Asia-Pacific Community" in June 2008 (Rudd 2008). He also renewed ties with Europe, achieved Australian membership in the G-20 process, and lobbied strongly for an Australian seat at the UN Security Council (Capie 2011; Gyngell 2008).

Australia's application was submitted in time to be considered at the ASEM 7 Summit along with that of the Russian Federation. Like Australia, Russia had unsuccessfully sought membership since the inception of ASEM but had failed to be accepted by either the Europeans or the Asians (de Crombrugghe 2011, 173). While the Europeans maintained that the "E" in ASEM stood for "EU", the Asians were uncomfortable being partnered with Russia and felt that their place was with Europe (Murray 2010). Russia therefore seized the opportunity created by the Australian application for a reevaluation of ASEM's membership criteria. The two applications were subsequently passed on for discussion and consideration at the 9'th ASEM Foreign Ministers' Meeting in Hanoi in May 2009.

In Hanoi, Russia and Australia's applications were "welcomed" by Foreign Ministers, although some technical matters stood in the way of immediate participation. Senior Officials were mandated to "work out modalities to enable both countries to formally join ASEM at the ASEM 8 Summit in Brussels in 2010" (ASEM 2009, §29). Clearly, the issue of categorisation remained unresolved, further indicated by the guarded invitation for ASEM Senior Officials to "discuss and propose criteria, principles, and procedures, on 
the basis of the Asia-Europe Cooperation Framework of 2000 regarding the future enlargement of ASEM” (ASEM 2009, §29). According to the AECF, any potential applicant needs to undergo a "two-key approach" whereby "a final decision on new participants will be made by consensus among all partners only after a candidate has first got the support of its partners within its region" (ASEM 2000, §28). While "Asia" and "Europe" are clearly understood as separate entities within the process, the membership of the two regions is not specified. Because of the uncertainties over the classification of Russia and the previous objection to Australian membership within the Asian caucus, the membership of both countries was highly contested.

While the Australian and Russian applications were being discussed, another potential ASEM member had appeared on the radar: New Zealand. The ASEM Senior Officials were further mandated to assess the membership "criteria, principles, and procedures", which was a result of "growing interest from other countries to join ASEM" (ASEM 2009, §29). Australia's exclusion from the process had essentially acted as a block on New Zealand membership. Once removed, New Zealand was forced to re-asses its options and eventually decided to apply to ASEM. The following section assesses New Zealand's path to ASEM membership.

\subsection{Hedging the Bets: New Zealand in ASEM}

Kevin Rudd's announcement of Australia's ASEM membership intentions dramatically altered the cost-benefit calculation for New Zealand. With the Australian application, attention was brought to an issue that had remained dormant for over a decade, and New Zealand was forced to re-evaluate the issue of membership. This section discusses the effects of Australian membership on New Zealand, and assesses how ASEM fit into the wider strategic context of New Zealand's engagement with the Asia-Pacific Region. 
Kevin Rudd's decision to seek ASEM membership for Australia came in the final months of Helen Clark's Labour-led government. The cost-benefit discussion that had lain dormant since ASEM's emergence was re-opened. While Rudd had sought membership based on an assessment of a clear benefit for Australia, in New Zealand the calculation was more defensive, based on fears of a diminished perception of New Zealand's involvement in the region. "Proponents of New Zealand membership suggested that being the only EAS state not a member of ASEM would give a negative impression of our willingness to play a full role as a regional partner of countries in Asia", suggests Tony Browne (2011, interview).

New Zealand's founding membership in the EAS signalled an acceptance from Asian leaders that New Zealand had a legitimate place at Asian decision making tables. For New Zealand, membership in the EAS had been an important diplomatic victory. APEC was also an important forum for New Zealand, but its membership was much more broadly constituted. The EAS was initially a much more exclusive club, with no members outside the immediate region. ${ }^{19}$ That New Zealand had a place there was a strong message of inclusion and legitimisation as a part of the future regional architecture of the broader "Asian" region. What were the costs of being the only EAS state outside of ASEM? The Beijing Summit had demonstrated the potential of ASEM as an important institution for Asia. For those championing a membership application, New Zealand's identity as an Asian partner was therefore at stake by not applying - even if it was unclear what concrete benefits would accrue from membership.

Others argued however that the Beijing Summit had been fortuitous - a product of particular international circumstances. It was unlikely that ASEM would continue to be a

\footnotetext{
19 The EAS has expanded to include the United States and Russia in 2010 so this is no longer true, but applied in 2008.
} 
worthwhile and productive forum. What was ASEM really going to bring to New Zealand? For a small country with limited ministerial resources at its disposal, a highlevel summit such as ASEM had significant funding implications. A further concern for New Zealand was whether it wanted to be seen to be meekly following Australia's lead. In 2008 - an election year - this was an undoubtedly important consideration. While one can only speculate, it seems that New Zealand's Labour Party Prime Minister Helen Clark was loathe to appear to be joining ASEM purely because Australia had done so, and that she was moreover somewhat disgruntled that New Zealand had not been informed of its Tasman partner's intentions. If Rudd had not seen fit to inform New Zealand of his intentions, why should New Zealand then apply to ASEM just because Australia had? The decision was therefore made within MFAT that New Zealand would not, at that time, seek membership to ASEM.

In November 2008 the national elections brought in a new, National-led government and a change in thinking on ASEM. The new Foreign Minister Murray McCully lost little time in questioning why, if the Australians were in ASEM, New Zealand was not also seeking membership. Again, one can only speculate, but it is conceivable that McCully may have been somewhat predisposed to consider that if the Labour Prime Minister Clark had been opposed to ASEM, it may be worth reassessing.

The issue had also been kept under review within MFAT. An internal MFAT report produced in early 2009 notes, "Clearly the Australian application has implications for New Zealand's position in relation to ASEM participation. Japan has for example already expressed surprise that we were not associated with the Australian initiative" (Heenan $2009, \S 54)$. The report made it clear that membership was not without its attendant resource implications, but that it would be "difficult, in terms of reinforcing New 
Zealand's commitment to and engagement with both Asia and Europe, to see New Zealand standing aside from participation, especially given the Australian move" (Heenan 2009, §54). The debate on ASEM was re-launched in mid-2009 and a report on ASEM was duly commissioned within MFAT. The document presented the arguments that had run their course in 2008. It considered that given New Zealand's active participation in other regional institutions, remaining out of ASEM might fundamentally harm New Zealand's credibility as a "natural partner" for states in the region. The document highlighted New Zealand's role in the EAS and the potentially detrimental effects of not supporting ASEM (Ministry of Foreign Affairs and Trade 2009). Based on this assessment, the newly elected National-led government supported joining ASEM, and New Zealand drafted letters to the two Asian coordinators - Cambodia and India seeking membership to the Asian side of the process. These were duly handed over by Murray McCully to Cambodia and India on the side-lines of the EAS and ARF Ministerial Meetings held in Hua Hin in early August.

New Zealand at this point faced a procedural challenge however. According to the AsiaEurope Cooperation Framework, any new application must be considered by the foreign ministers before that country can be accepted at a Summit meeting (ASEM 2000, §8). New Zealand wished to join ASEM at the same time as the Australians during the ASEM 8 Summit in Brussels, scheduled for October 2010, but had missed its chance to be considered alongside Australia and at the Hanoi FMM in July 2009. To remedy this, the Cambodian Senior Official suggested that it was not indicated in the ASEM regulations that an application needed to be considered at a formal Foreign Ministers' Meeting, and successfully argued for out-of-session Ministerial approval by correspondence (Browne 2011, interview). 
The question of categorisation remained unresolved however. While Australia and New Zealand had applied to the Asian side of the meeting, Russia's membership remained contentious and threatened the chances of Australia and New Zealand from being admitted to the Asian side: neither the Asians nor the Europeans were willing to accept Russia. To break the log-jam, the Singaporeans had proposed a compromise that involved creating a "Temporary Third Category" to house Russia and Australia. This proposal was tabled by Cambodia at the SOM in Stockholm on the $1^{\text {st }}$ October 2009, and fleshed out at the Madrid SOM on 25 January 2010 (de Crombrugghe 2011, 175-177). The Madrid SOM agreed that the Temporary Third Category arrangement would be used to allow Australian and Russian involvement in ASEM, without permanently resolving the matter of their ultimate categorisation.

When Wellington's application was formalised in April 2010, the Europeans rapidly endorsed New Zealand's participation. To avoid re-opening any question of categorisation, it was determined that although New Zealand had applied to join the Asian side, they would follow Australia and Russia in acceding via the Temporary Third Category mechanism. The Asians agreed that New Zealand should join via this route, and the decision was formally reached at the Phnom Penh SOM held from 5-6 May 2010. New Zealand was invited to attend the Brussels SOM from 13-15 July, and later returned to Brussels for the ASEM 8 Summit on 4 and 5 October where the three new members Australia, New Zealand and Russia - were formally welcomed (ASEM 2010).

New Zealand's path to ASEM membership was therefore distinct, though connected, to that of Australia. Australian membership came in the context of Kevin Rudd's foreignpolicy oriented leadership and was motivated by the prospect of taking part in a highlevel decision making forum that suddenly seemed to be gaining traction. New Zealand's 
application was motivated more by concern over a potential loss of credibility within the emerging Asian regional architecture and the attendant political and economic vulnerability that may have resulted from this. In different ways, Australia and New Zealand's can both be understood in defensive terms - to avoid exclusion from a process that seemed deeply connected to regional integration in Asia.

There is no obvious indication of any process of "spillover" from trans-Tasman integration to Australia-New Zealand cooperation in international relations in the ASEM case however. Indeed, this empirical story indicates the significant role that individuals - especially leaders - within Australia and New Zealand play in shaping the foreign policy decisions of both countries. Yet, New Zealand was clearly affected by Australia's bilateral relations with key Asian states in ASEM, and was furthermore induced to apply to ASEM largely because of Australian action. Building on these conclusions, the following section discusses what separate applications indicate about the drivers of trans-Tasman integration.

\subsection{Understanding Convergence and Divergence}

Why was there no apparent "spillover" from internal trans-Tasman policy cooperation to external cooperation in the ASEM case? What explains deep trans-Tasman cooperation in internal (market) policy areas, but not in this external case? This thesis does not argue that non-cooperation on ASEM was particularly unexpected, rather that the case demonstrates that trans-Tasman integration is not driven evenly across issue areas.

A number of factors explain the lack of coordination. As a pre-existing institution, ASEM had a set of established modalities relating to form as well as function. As Murray notes, 
"Australia did not join as a creator of ASEM and so it inherits the norms and practices that are in place" (Murray 2010, 57). The form of ASEM as a binary (Asia-Europe) pairing of regions means that Australia and New Zealand wished to join an existing "regional" grouping - Asia. Considered in the context of Australia and New Zealand's promotion of their role as legitimate partners in the Asian region who cooperate in key regional institutions, a close Australia-New Zealand cooperative effort may have overemphasised the trans-Tasman connection. This may have been especially detrimental to Rudd's ambitions for Australia at the regional and global level.

ASEM is also a political process, with the leader-level summits the climax of the bi-yearly meeting cycle. These high profile events offer political leaders from Asia and Europe the opportunity to engage with one another and to be seen engaging with one another. Members are motivated, as the former Executive Director of ASEF notes, by a desire "to be sitting at the table, whatever the topic discussed could be" (Girard 2011, interview). Australia and New Zealand were no different. As he left to represent New Zealand at the ASEM 8 Summit, McCully noted, "This is an historic occasion for New Zealand, as it is the first time we will be taking a seat at the top table of a meeting of Asian and European leaders" (New Zealand Government 2010). For New Zealand, ASEM represented "a further opportunity to advance New Zealand's bilateral interests as it would enable the Prime Minister and Foreign Minister access to 43 counterparts" (Ministry of Foreign Affairs and Trade 2009, p.5, §8). Understood as a forum to advance bilateral aims, New Zealand would have been similarly unlikely to place too much emphasis on the transTasman relationship. Applying as CER would have been counterproductive if an application was designed to promote the legitimacy of Australia and New Zealand as Asian partners. 
Australia and New Zealand had not previously coordinated on the possibility of ASEM membership. With no precedent of doing so, coordination would have had a higher political cost for respective Australian and New Zealand governments, both domestically and regionally. Without issue-relevant trans-Tasman institutions available to reduce these costs, cooperation was unlikely. As the previous chapters have outlined, the transTasman institutional framework that has developed during the course of integration is highly issue-specific. Without a correlation between the issues to be dealt with in ASEM and those regulated under trans-Tasman integration, trans-Tasman institutions and actors were not available to policymakers in Australia and New Zealand as an option for a policy response. An Australian official interviewed for this research was quick to suggest that assuming a degree of trans-Tasman coordination in such an event such as an application to a forum like ASEM "should not be overstated". While it is not uncommon for Australian officials to consult or inform their New Zealand counterparts about particular events, there is no set procedure for doing so (Australian Official 2011, interview).

\subsection{Conclusion}

Australia and New Zealand's separate applications to ASEM should not be considered an abnormal case. Rather they should be seen as an indication of the baseline of transTasman external coordination. The existing institutional makeup of ASEM; its political nature; the context of Australia and New Zealand's strategic engagement with the Asian region; and Australian Prime Minister Kevin Rudd's sudden announcement of Australia's intention to seek membership all contribute to explaining non-coordination between the two countries in their membership applications. 
While these factors seem at first glance to be diverse, in fact they all support the central claim of this thesis. Spillover in trans-Tasman integration reflects the determinative role of issue-specific trans-Tasman institutions that are part of a decentralised governance structure. These institutions offer national decision makers with a means of jointly understanding and formulating policy in response to international, domestic or regional imperatives. In issue-areas in which they exist, these institutions also shape the preferences and perceptions of trans-Tasman actors, increasing the appeal of transTasman cooperation. Intra-regional (internal) trans-Tasman cooperation did not develop into inter-regional (external) cooperation in the ASEM case because there were no available institutions that could facilitate this process - ASEM was outside of the policy space governed by trans-Tasman integration. This supports the observation that there is both integration and divergence between Australia and New Zealand (Patman 2001; Goff 2001). Rather than seeing this distinction as an inherent division between politics and economics however, this thesis argues that it is due to the particular, decentralised institutional trajectory of trans-Tasman integration. 


\section{Six}

\section{Conclusion}

Australia and New Zealand's choice to negotiate with ASEAN as CER suggested spillover from trans-Tasman cooperation in internal (intra-regional) policy areas into external areas of competence. As such, one could expect that such joint cooperation might be replicated in other areas. Australia and New Zealand's independent applications to the Asia-Europe Meeting (ASEM) were however an indication that joint cooperation would not occur in all instances. This raised an intriguing empirical puzzle. When and why does trans-Tasman cooperation in internal policy areas spill over into external cooperation in foreign or trade policy? This project hypothesised that spillover is determined by the availability of issue-specific trans-Tasman institutions for use by Australian and New Zealand policy makers. Comparative analysis of two case studies - CER-ASEAN relations and trade negotiations; and Australian and New Zealand entry to the Asia-Europe Meeting (ASEM) - confirmed this hypothesis.

This concluding chapter proceeds in three main sections. In the first, the main findings of the project are presented. These findings affirm the central contention of the project, that spillover from internal trans-Tasman policy cooperation to external cooperation with ASEAN was the product of a particular set of issue-specific trans-Tasman institutions.

The second part discusses the implications of this research. The project has contributed to the wider body of comparative literature on regional integration as well as the emerging body of literature on interregionalism. The research results illuminate the trans-Tasman and CER-ASEAN case as one that provides a valuable testing ground for 
theoretical work that has been developed in Europe and elsewhere. There are also policy and societal implications of these results; these are duly discussed.

This project has uncovered a number of gaps in the knowledge about Trans-Tasman integration in particular and the relationship between internal processes of regional integration and external policy cooperation of states within regions more generally. The third section outlines an empirically-driven research agenda that can address these gaps. This includes further research on CER as well as comparative research that will enable the localised, case-specific conclusions reached in this project to be tested against a wider spectrum of cases.

A final section concludes.

\subsection{Summary of Main Findings}

Chapter Three provided the historical context for the study. It first analysed transTasman economic integration under NAFTA and CER. Trans-Tasman integration has been motivated by changes in the international environment, as well as changing domestic contexts. The UK's application to join the EEC encouraged Australia and New Zealand to consider alternative markets, while domestic pulp and paper industry interests in New Zealand provided a further, powerful motivation to gain access to the Australian market. The UK's 1973 entry to the EEC, the failure to secure multilateral liberalisation of agricultural products at the GATT and frustration with slow liberalisation under NAFTA led to the reform and ultimately the replacement of NAFTA.

As hypothesised, trans-Tasman intra-regional institutions were a significant factor in enabling integration. NAFTA's ministerial meetings helped to alter the cost/benefit analysis of further trans-Tasman integration by reducing the transaction uncertainties 
of policy coordination. The socialisation of trans-Tasman actors was complementary to this process. This section therefore provided initial confirmation of this project's hypothesis.

The second section of Chapter Three outlined historical Australia-ASEAN and New Zealand-ASEAN relations. These relations began to significantly mature following the UK's entry into the EEC, with Australia and then New Zealand becoming the first two countries to become official ASEAN Dialogue Partners. This suggested that Australia and New Zealand's reactions to the UK's EEC accession were not limited to an increase in trans-Tasman integration. Rather, trans-Tasman integration was part of a systematic reorientation of policy towards an emphasis on the Asia-Pacific region. Archival research revealed a clear convergence of ASEAN policy between Australia and New Zealand, but no formal cooperative efforts. Internal New Zealand Ministry of Foreign Affairs communications indicated hesitation to promote formal trans-Tasman cooperation on ASEAN due to fears that this would be perceived as inconsistent with integration under NAFTA. No evidence was found to suggest that Australia and New Zealand were convinced that trade liberalisation with one another, let alone with ASEAN, was desirable at this point.

Chapter Four examined the process that led to AANZFTA negotiations. The first section outlined the formal negotiation process for AANZFTA. Negotiations were physically structured as an interregional endeavour, with the Australian and New Zealand negotiators at one end of the room, and the ASEAN representatives at the other. Negotiators were aware of engaging in interregionalism, and Australia and New Zealand were considered by ASEAN, and considered themselves, as representing a distinct region - CER. 
To understand the basis for Australia-New Zealand cooperation as CER, the next two sections recreated the interregional process as it developed during the 1990s. The first of these looked at how and why Australia and New Zealand established joint relations with ASEAN. Initial CER-AESAN relations were established at an informal interregional basis at the Ministerial level, as the result of a suggestion from an ASEAN member. This was enabled by the historical precedent set by past trans-Tasman integration. The institutional design of CER - open and liberal - was consistent with the establishment of relations with other regions. After initial Ministerial relations were established they rapidly expanded to include other trans-Tasman institutional actors, with particular attention in this project being paid to the area of standard-setting. The issue specific nature of these institutions meant that spillover was channelled to issue areas in which there was a history of trans-Tasman integration.

The second section focussed on the deepening and broadening of CER-ASEAN relations. It asked who drove spillover. It found that government officials played an important role in establishing interregional relations, anticipating further development, and coordinating relations. At the same time, these officials appeared willing to allow other actors to play determinative roles in shaping the scope and speed of interregionalism. This included delegation to and inclusion of actors within Trans-Tasman institutions. These institutions not only made themselves available to achieve policy makers' goals, they in fact became agents of interregionalism. Once CER-ASEAN meetings in standardsetting began, they were formalised and regularised. They began to take place annually, while a Memorandum of Understanding on the expected outcomes of the relationship was signed between relevant parties and a CER-ASEAN work programme on standard- 
setting was implemented. This multi-level interregional cooperation formed the basis for later trade negotiations.

Why did Australia and New Zealand enter joint negotiations with ASEAN, while operating individually in other contexts? Chapter Five examined Australia and New Zealand's applications to the Asia-Europe Meeting (ASEM) in order to answer this question. A first section outlined the international context of both countries' application to ASEM. Australia had historically sought ASEM membership but had been stymied by poor relations with key states in Asia. Australian interest, pushed particularly by an Asia-focussed Prime Minister Kevin Rudd, was rekindled by ASEM's apparent potential as a decision-making forum in the context of the Global Financial Crisis. Australian membership was part of a broad emphasis on Australia's role as a dominant player in emerging Asian regional structures.

New Zealand on the other hand had not originally sought membership as it was perceived that it would be of little appreciable benefit, while there might be substantial resource implications in ensuring representation of senior officials at ASEM meetings. The 2008 Australian membership bid however led to New Zealand concerns of exclusion from a forum that was important for Asian states. It was concluded that this would impact negatively on New Zealand's credibility as a legitimate partner in the region, and an application was duly lodged. The Australian application was the main determinant of the New Zealand membership bid, but there was no coordination or consultation between the two countries during the application process.

From this empirical assessment, several conclusions were able to be drawn. ASEM applications illustrate that Australia and New Zealand do not necessarily coordinate their foreign policies. The two have differing strategic goals in the region; Australia has 
middle power ambitions and the resources to fulfil them, while New Zealand has more limited goals and capabilities. The trans-Tasman relationship affected the cost-benefit calculation within the New Zealand Ministry of Foreign Affairs and Trade (MFAT), but this was not manifested in any form of spillover in terms of the development of joint Australia-New Zealand capabilities to act in international relations.

What then accounted for spillover in the CER-ASEAN relationship? Two main factors were evident. Firstly and primarily, the creation of issue-specific trans-Tasman institutions established a precedent for Australia-New Zealand cooperation in those issue areas beyond the trans-Tasman context. When encouraged by an external agent (ASEAN), it was not a great extension of institutional competences for these transTasman bodies to engage in inter-regional dialogue with counterpart institutions in ASEAN. This suggests that once issue-specific institutions are established, it is a manageable step to extend the context of their operation to beyond the intra-regional level in which they were created. As such, spillover from intra-regional to interregional competence was channelled to specific issue areas. The determining factor was the issue-specific nature of available trans-Tasman institutions.

Secondly, the operational scope and context of institutions shaped the preferences of actors within them. The Executive Director of Standards New Zealand Peter Davenport, who operated in an institutional context that emphasised trans-Tasman cooperation in standard-setting, saw it as a logical move to establish an over-arching trans-Tasman body that would act as a counterpart to the ASEAN Consultative Committee on Standards and Quality (ACCSQ). The creation of an inter-regional governance space for standard-setting created the demand for appropriate regulatory institutions. That Davenport's proposed Australia-New Zealand Consultative Committee on Standards and 
Quality (ANZCCSQ) did not eventuate is not a counterfactual; indeed it suggests that existing institutions were ultimately able to be adapted for use in an interregional context. Spillover was therefore driven by the demand for institutions that could operate in an interregional context.

In both the CER-ASEAN and ASEM cases, external factors drove Australia and New Zealand to seek involvement in a new regional configuration. The availability of existing trans-Tasman institutions lowered the transaction cost of a joint response in the CERASEAN case. Once the interregional relationship was established, trans-Tasman institutions were adapted to fulfil an interregional role, deepening and broadening the CER-ASEAN relationship.

\subsection{Implications of the Research Findings: Looking Forward}

Beyond the immediate conclusions about the process of policy spillover in the transTasman relationship that may be drawn from this research, the findings of this project have broader implications. There are theoretical and policy aspects of these implications. This section addresses these in turn.

\section{Implications for theory}

This thesis was empirically rather than theoretically driven, but the conclusions reached speak to a number of theoretical points. These pertain to research on regionalism as well as interregionalism. This thesis demonstrated for instance the importance of internal as well as external factors in determining the process and outcomes of regional integration. This project focussed primarily on internal variables, but some observations regarding the international environment bear making. The trans-Tasman case validates causal arguments that point to the "contagious" nature of regional trading agreements 
(Mattli 1999; Baldwin and Jaimovich 2010; Baldwin 1997, 1995), especially with regard to the relatively "closed" trans-Tasman integration under NAFTA. Trans-Tasman regionalism was also however a product of multilateralism's failure (Krugman 1993, 1991; Bhagwati 1993). CER was very much a product of the failure to ensure that transTasman agricultural interests were safeguarded through multilateral liberalisation at the GATT. Again, in the late 2000s failure at the WTO encouraged AANZFTA. As such, the failure to achieve optimal multilateral liberalisation resulted in an "open" form of regionalism (CER) that was consistent with the multilateral regime. Do different international forces or events encourage different forms of regional integration?

Internally, this project demonstrated the importance of institutions in shaping the scope of policy spillover. The presence of available, issue-relevant institutions was shown to lower the costs of joint political action between polities beyond the original scope of cooperation. Institutions were adaptable to use in a new, external context. TransTasman overlap in key regulatory areas such as standard-setting enabled Australia and New Zealand to cooperate as CER with ASEAN. At a broad level, Australia and New Zealand were able to utilise existing institutions to rationally pursue strategic goals of engaging with ASEAN. Australian standard-setting bodies also saw the potential of existing trans-Tasman inter-institutional relationships as a means of advancing strategic interests in developing region-wide building standards. At the level of individuals' interactions with regional institutions, the latter also shaped the way actors understood and engaged with the world.

For analyses of regions and regional integration, this thesis has demonstrated the worth of a multi-level analytical approach that considers external as well as internal factors. The importance of multiple levels of analysis also holds true for interregionalism. This 
thesis has contributed a further empirical case to the growing literature in this area. It has also broadened the range of analytical approaches adopted.

While much of the existing literature focuses on the potential "functions" of interregionalism, this project chose instead to examine the basis of external cooperation between regional states. In doing so it extended studies in this area by modifying actorness as an explanatory variable. This project adopted a more nuanced approach to the use of this variable, in particular by suggesting that actorness need not be considered a general quality of the region. This project instead adopted an approach that conceived of actorness as an issue-specific quality. In the present study, this was beneficial as it allowed for an understanding of the trans-Tasman region as one that can "act" externally in some issue areas, but not others. A more flexible and non-Eurocentric conception of actorness as an explanatory variable may prove worthwhile for observers of other cases of non-EU interregionalism.

\section{Implications for policy}

This project does not aim to be prescriptive, but there are some general policy observations that can be drawn from this research. With respect to AANZFTA and the CER-ASEAN relationship, it seems safe to affirm that economic integration between the two regions is destined to increase from this point. AANZFTA is a forward-looking agreement that liberalises goods and services in a single undertaking. That CER-ASEAN integration will continue to expand over the coming decades is not news for policy makers in Australia and New Zealand, but the full implications of the relationship may yet be unrecognised by the business community as well as the general public. Australia and New Zealand's turn towards Asia began in the 1970s, and the economies of the two countries will only become increasingly interlinked with those of Asia. While the rise of 
China and India are the headlines, the relationship between the two CER countries and ASEAN will be one of growing economic, political and cultural importance.

An area that holds particular potential for evolution in the CER-ASEAN relationship is the institutionalised relationships between regional bodies in CER and ASEAN such as in standard setting. The trans-Tasman example demonstrated the role that regional institutions play in determining the scope of spillover. As CER-ASEAN relationships deepen, it is conceivable that bodies in areas such as standard-setting emerge on a CERASEAN foundation. This will be context dependent however; the CER-ASEAN model of integration is one model among many. Other agreements such as the Trans-Pacific Partnership Agreement (TPPA) may provide an alternative basis for such developments. In any of these eventualities, this thesis demonstrates the determinative role that institutions will play in shaping the scope for such cooperation. Are Australia and New Zealand trying to 'upload' their liberal, democratic institutions to the regional level through engagement with ASEAN and other regional mechanisms? As Australia and New Zealand institutionalise cooperation with other actors in the region, will they increasingly find their hands tied together in certain issue areas?

This thesis has taken no normative stance on whether further external trans-Tasman cooperation would be desirable, choosing rather to assess the "how" and "when" of the matter. The institutional change involved in spillover follows an incremental logic, to which there is some sense of path dependency. Should trans-Tasman policy makers wish to achieve joint cooperation in other areas, establishing issue-specific institutions or arrangements with a trans-Tasman orientation may be an importance first step. The recent institutionalisation of trans-Tasman Ministerial Summits may provide a more generalised possibility for the articulation of new goals, and for the identities, self- 
images and preferences of political actors on both sides of the Tasman to converge. The desirability of further external trans-Tasman cooperation may or may not be moot, but its probability seems assured.

In terms of ASEM, the policy implications of membership are more tenuous. Whether the forum will be of direct benefit to New Zealand, if not necessarily Australia, remains in doubt. Ironically however, although the two countries did not coordinate their applications, they find themselves working in close proximity within the Temporary Third Category. It may be that ASEM ultimately proves to be a forum in which other forms of joint external trans-Tasman capacities evolve. Russia's membership in ASEM means there continues to be no immediate solution to the categorisation posed by the Temporary Third Category countries. This institutional limbo may act as a catalyst for Australian and New Zealand officials to formally cooperate in larger regional fora. If not for its direct political relevance to Australia and New Zealand, ASEM may therefore be an institution to observe.

\subsection{A Future Research Agenda}

This project was motivated by an empirical research puzzle and has addressed this puzzle. In doing so, it has uncovered a number of gaps in existing knowledge about CER. There are also ways in which this project's research can be extended to include other case studies from other regions. This would enable a broader testing of hypotheses developed in the limited context of trans-Tasman integration.

\section{Advancing a trans-Tasman research agenda}

The two cases analysed in this project were chosen based on an empirical observation of variance in the way that Australia and New Zealand act in international relations. It was 
decided to privilege depth in these two cases over breadth of case selection. To more conclusively determine the relationship between trans-Tasman integration and Australia and New Zealand's foreign and trade policy, the sample size should be increased through inclusion of several other cases in a larger research project.

Such enlargement of an Australia/New Zealand-based research agenda could take place along several axes. In the first instance, it would be beneficial to focus directly on trade negotiations. What distinguishes AANZFTA from other trade negotiations where there has not been trans-Tasman cooperation? One case that bears examination is the Australia-China and New Zealand-China Free Trade Agreements. Analysis of these agreements with reference to AANZFTA would help to explain instances of noncooperation between Australia and New Zealand. Negotiations on all three agreements overlapped; why did Australia and New Zealand not cooperate on an agreement with China, given their cooperation with ASEAN? A trade-focussed research agenda that includes cases of trans-Tasman cooperation and non-cooperation would provide a nuanced understanding the externalities of internal trans-Tasman cooperation on economic policy.

Another way of expanding this research agenda would be to compare Australian and New Zealand membership in regional institutions and fora other than ASEM. The focus of this project has been on how intra-regional factors affect the scope of external Australia-New Zealand cooperation. Assessing the extent that the international context of engagement affects the scope for Australia-New Zealand cooperation is an equally important endeavour. One ironic outcome of Australia and New Zealand's ASEM membership for instance is that after independent applications they now find themselves cooperating closely within the "Temporary Third Category" mechanism. Will 
cooperation in this context spill over into cooperation in others? How does the organisational structure of other regional institutions shape the way Australia and New Zealand cooperate?

\section{Towards a Comparative Research Agenda}

Broadening the scope of empirical research on the trans-Tasman relationship will address localised gaps in our knowledge. This project also speaks to research questions that may be addressed by a broader, comparative research agenda. The current project has underscored the importance of regional institutions that have (some) supranational characteristics. How do different regional institutions affect the ability of regions to engage in inter-regional negotiations? When and why are countries induced to negotiate as regions with external partners?

In some instances countries negotiate as regions with external partners, while in others they retain sovereign control over these negotiations. To understand this variation of outcome there are a number of cases with which the CER-ASEAN relationship is apt to be compared. EU-ASEAN relations commenced in 1971, but recent efforts to achieve an inter-regional Free Trade Agreement between the two partners have been unsuccessful. Instead, the EU has now entered into trade negotiations with individual ASEAN states. EU-Mercosur trade negotiations - despite efforts that have spanned over a decade have also failed to come to fruition. EU-EFTA (European Free Trade Area) negotiations resulted in the creation of the European Economic Area (EEA) on 1 January 1994, although Switzerland (an EFTA state) did not join due to a constitutional referendum. Relations between the EU and the Visegrád group (the Czech Republic, Poland, Slovakia and Hungary) in the 1990s aimed to allow the four Visegrád states to enter the EU - a goal which was ultimately achieved. 
These cases are contemporaneous and they have also resulted in varying levels of success. Moreover, these cases include the EU and ASEAN in differing inter-regional pairings. Such a comparative research agenda would allow for an empirically and methodologically robust inquiry that will be able to test theoretical assumptions about the impact of, for instance, asymmetries of power, economic development and political organisation within and between regions over a larger sample size.

\subsection{Final Conclusions}

The two cases presented in this thesis painted quite different pictures of the transTasman relationship. The constant theme running between them has been the imperative for Australia and New Zealand to play a role in defining "Asia". AANZFTA, ultimately is as symbolic an affirmation of Australia and New Zealand's commitment to the Asian region as is joining the Asia-Europe Meeting. Ensuring that the membership and 'architecture' of the region get defined in a way that is acceptable to Australia and New Zealand is of vital national significance. Determining the geographic, ideational and economic limits to the region is a political process and there will be clear winners and losers. Australia and New Zealand are carefully and methodically preparing for the eventuality of a region-wide free trade agreement emerging by ensuring that they have, in the words of an official interviewed for this research, "a horse in every race" (New Zealand Ministry Official 2011, interview).

The over-riding importance of participating in Asian regionalism makes it all the more intriguing that Australia and New Zealand varied their approach to engagement, with close cooperation and joint approaches in only one of the two cases explored here. An issue-specific understanding of 'actorness' in the trans-Tasman case is central to explaining this divergence. In making this case this thesis has made a clear contribution 
to our understanding of the way institutions shape the way regions act in international relations. 


\section{Works Cited}

Aggarwal, Vinod K. 2004. "Explaining Trends in EU Interregionalism." In European Union Trade Strategies: Between Globalism and Regionalism, edited by Vinod K Aggarwal and Edward Fogarty, 207-240. London: Palgrave.

Allen, David, and Michael Smith. 1990. "Western Europe's Presence in the Contemporary International Arena." Review of International Studies no. 16 (1):19-37.

Andre, Pamela, Stephen Payton, and John Mills. 2003. The Negotiation of the Australia New Zealand Closer Economic Relations Trade Agreement 1983. Canberra and Wellington: Australian Deptartment of Foreign Affairs and Trade and New Zealand Ministry of Foreign Affairs and Trade.

ASEAN-Australia Forum. 1994. Joint Press Release of the 16th ASEAN-Australia Forum. Canberra, Australia, 3-4 May, .

ASEAN and CER. 2000. Framework for the AFTA-CER Closer Economic Partnership. http://aanzfta.asean.org/.

ASEAN and CER Ministers. 1995. "Joint Press Statement on Informal Consultations Between AEM and the Ministers from the CER Countries. Bandar Seri Begawan, Brunei Darussalam. 9 September."

- - . 1996. Joint Press Release for the Second Informal AEM-CER Consultations; Jakarta, Indonesia, 13 September. www.asean.org/6273.htm.

- - . 2000. Joint Press Statement of the Fifth Consultations Between the ASEAN Economic Ministers and the Ministers of the CER, Chiang Mai, Thailand, 6 October, 2000. http://aanzfta.asean.org/uploads/jms/AEM-CER 05.pdf.

- - . 2002. Joint Press Statement on the Seventh Consultation Between the ASEAN Economic Ministers and Ministers of the CER; 14 September 2002, Bandar Seri Begawan, Brunei Darussalam. http://www.aseansec.org/newdata/aem34 doc6.htm.

- - . 2004a. Guiding Principles for Negotiation on ASEAN-Australia and New Zealand Free Trade Area (FTA). http://www.aseansec.org/16799.htm.

- - . 2004b. Joint Declaration of the Leaders at the ASEAN-Australia and New Zealand Commemorative Summit; Vientiane, 30 November 2004. http://www.asean.org/16796.htm.

- - . 2004c. Joint Media Statement at the Ninth AEM-CER Consultations; Jakarta, 5 September, 2004. http://www.asean.org/16381.htm.

- - . 2009. Joint Media Statement on the Signing of the Agreement Establishing the ASEANAustralia-New Zealand Free Trade Area; Cha-am, Thailand, 27 February 2009. http://www.aseansec.org/22256.htm.

ASEAN Heads of State and Government. 1995. Bankok Summit Declaration of 1995; Bangkok, 14-15 December. http://www.asean.org/5189.htm.

ASEAN Ministers of Foreign Affairs. 2004. Joint Communique of the 37th ASEAN Ministerial Meeting: Jakarta, 29-30 June, 2004. http://www.asean.org/16192.htm.

ASEM. 1996. Chairman's Statement of the Asia-Europe Meeting, Bangkok, 2 March 1996.

- - . 2000. Asia-Europe Cooperation Framework. http://www.aseminfoboard.org.

- - . 2008. Chair's Statement of the Seventh Asia-Europe Meeting, 24-25 October, at Beijing.

- - . 2009. Chair's Statement of the Ninth ASEM Foreign Ministers' Meeting. Ha Noi, 25-26 May.

- - - 2010. Chair's Statement of the Eighth Asia-Europe Meeting, Brussels, 4-5 October 2010.

ASEM InfoBoard. 2011. About ASEM: Structure n.d. [cited 25 November 2011]. Available from http://www.aseminfoboard.org/About/Structure/.

Australian Bureau of Statistics. 1975. Year Book Australia, No. 62. Canberra: ABS.

-- - 1981. Year Book Australia, No. 65. Canberra: ABS.

-- . 1986. Year Book Australia, No. 70. Canberra: ABS.

- - . 1992. Year Book Australia, No. 75. Canberra: ABS.

- - . 1996. Year Book Australia, No. 78. Canberra: ABS. 
-- - 2001. Year Book Australia, No. 83. Canberra: ABS.

Australian Official. 2011. Telephone Interview with Author. Wellington, 10 November.

Baldwin, Richard E. 1995. "A Domino Theory of Regionalism." In Expanding Membership in the European Union, edited by Richard E. Baldwin, Pertti Haapararanta and Jaako Kiander, 25-48. Cambridge: Cambridge University Press.

- - . 1997. "The Causes of Regionalism." The World Economy no. 20 (7):865-888.

Baldwin, Richard E., and Dany Jaimovich. 2010. Are Free Trade Agreements Contagious? CEPR Discussion Paper 7904, www.cepr.org/pubs/dps/DP7904.asp.asp.

Bentick, Brian, and Committee for Economic Development of Australia. 1962. Prospects of an Australia-New Zealand Economic Union. Melbourne: Committee for Economic Development of Australia.

Bhagwati, Jagdish. 1993. "Regionalism and Multilateralism: An Overview." In New Dimensions in Regional Integration, edited by Jaime De Melo and Arvind Panagariya, 22-51. Cambridge: Cambridge University Press.

- - . 1999. "Regionalism and Multilateralism: An Overview." In Trading Blocs: Alternative Approaches to Analyzing Preferential Trade Agreements, edited by Jagdish Bhagwati, Pravin Krishna and Arvind Panagariya, 3-32. Cambridge: MIT Press.

Bollard, Alan. 1986. "The Economic Relations Agreement Between Australia and New Zealand: A Tentative Appraisal." JCMS: Journal of Common Market Studies no. 25 (2):89-107. doi: 10.1111/j.1468-5965.1986.tb00283.x.

Bollard, Alan, and David Mayes. 1992. "Regionalism and the Pacific Rim." JCMS: Journal of Common Market Studies no. 30 (2):195-210.

Börzel, Tanja A, and Thomas Risse. 2009. Diffusing (Inter-) Regionalism: The EU as a Model of Regional Integration. In KFG Working Paper Series. Freie Universitat Berlin: KollegForschergruppe (KFG), "The Transformative Power of Europe".

Boxall, Graham. 1996a. Untitled. Fax from Ministry of Commerce to John Hulbert (JAS-ANZ), Peter Davenport (SNZ), Jack Garside (Telarc), Andrew Corney (MSL). 4 April.

- - . 1996b. Untitled. Fax from Ministry of Commerce to Peter Davenport (SNZ), Malcolm Bell (Telarc), Steve Keeling (JAS-ANZ). 29 February.

Browne, Tony. 2011. Interview by Author. Wellington, 24 November.

Capie, David. 2011. "Bridging Asia and Europe? Australia and New Zealand Membership in ASEM." In The Asia-Europe Meeting: Contributing to a New Global Governance Architecture, edited by Sebastian Bersick and Paul van der Velde, 159-170. Amsterdam: Amsterdam University Press.

Carroll, Peter. 1995. "Mutual Recognition: Origins and Implementation." Australian Journal of Public Administration no. 54 (1):35-45.

- - . 1999. "Globalization and Policy Convergence: The Adoption of Mutual Recognition in the European Union and Australia." Public Management Review no. 1 (3):387-405.

Chase, Kerry. 2003. "Economic Interests and Regional Trading Arrangements: The Case of NAFTA." International Organization no. 57 (1):137-174.

Commonwealth-State Relations Secretariat. 2009. Commonwealth State Ministerial Councils - a Compendium. Commonwealth Government - Department of the Prime Minister and Cabinet.

Commonwealth Bureau of Census and Statistics. 1908. Official Year Book of the Commonwealth of Australia, No. 1. Melbourne: McCarron, Bird and Co.

-- . 1912. Official Year Book of the Commonwealth of Australia, No. 5. Melbourne: McCarron, Bird and Co.

-- . 1916. Official Year Book of the Commonwealth of Australia, No. 9. Melbourne: McCarron, Bird and Co.

- - . 1921. Official Year Book of the Commonwealth of Australia, No. 14. Melbourne: Government Printer.

- - . 1926. Official Year Book of the Commonwealth of Australia, No. 19. Melbourne: Government Printer. 
-- . 1930. Official Year Book of the Commonwealth of Australia, No. 24. Canberra: Government Printer.

-- . 1931. Official Year Book of the Commonwealth of Australia, No. 24. Canberra: Government Printer.

-- - 1936. Official Year Book of the Commonwealth of Australia, No. 29. Canberra: Commonwealth Government Printer.

-- . 1939. Official Year Book of the Commonwealth of Australia, No. 35. Canberra: Commonwealth Government Printer.

- - . 1945. Official Year Book of the Commonwealth of Australia, No. 37. Canberra: Commonwealth Government Printer.

-- - 1953. Official Year Book of the Commonwealth of Australia, No. 39. Canberra: Commonwealth Government Printer.

---. 1956. Official Year Book of the Commonwealth of Australia, No. 42. Canberra: Commonwealth Government Printer.

-- . 1962. Official Year Book of the Commonwealth of Australia, No. 48. Canberra: Commonwealth Government Printer.

--- 1966. Official Year Book of the Commonwealth of Australia, No. 52. Canberra: Commonwealth Government Printer.

- - . 1971. Official Year Book of the Commonwealth of Australia, No. 57. Canberra: Commonwealth Government Printer.

Cowles, Maria Green. 1995. "Setting the Agenda for a New Europe: The ERT and th EC 1992." JCMS: Journal of Common Market Studies no. 33 (4):501-526.

Crean, Simon. 2009. Tabling of the ASEAN-Australia-New Zealand Free Trade Agreement. Speech by the Minister for Trade given in the Australian Parliament: 17 March.

Davenport, Peter. 1996a. "AFTA/CER: ACCSQ-CER Meeting, Brunei, 17/1/96." Fax from Standards NZ to Graham Boxall (Ministry of Commerce). 29 February (File 101/14).

- - . 1996b. "Attendance at the First ACCSQ Meeting." Confidential Memorandum from Standards New Zealand to MFAT. 24 January (File 118/154).

de Crombrugghe, Bertrand. 2011. "ASEM's Future Enlargement: The Way Forward." In The AsiaEurope Meeting: Contributing to a New Global Governance Architecture, edited by Sebastian Bersick and Paul van der Velde, 171-185. Amsterdam: Amsterdam University Press.

Dent, Christopher M. 2003. "Networking the Region? The Emergence and Impact of Asia-Pacific Bilateral Free Trade Agreement Projects." The Pacific Review no. 16 (1):1-28. doi: 10.1080/0951274032000043226.

- - . 2004. "The Asia-Europe Meeting and Inter-Regionalism: Toward a Theory of Multilateral Utility." Asian Survey no. 44 (2):213-236.

Department of Foreign Affairs and Trade, and Standards Australia. 1996. "A Regional Path to International Building Standards." Paper Presented at the 17th ASEAN-Australia Forum:12-13 March.

Doctor, Mahrukh. 2007. "Why Bother With Inter-Regionalism? Negotiations for a European UnionMercosur Agreement." JCMS: Journal of Common Market Studies no. 45 (2):281-314. doi: 10.1111/j.1468-5965.2007.00712.x.

Doidge, Mathew. 2004. "Inter-Regionalism and Regional Actors: The EU-ASEAN Example." In The Eurasian Space: Far More than Two Continents, edited by Wim Stokhof, Paul van der Velde and Yeo Lay Hwee, 39-57. Singapore: ISEAS Publications.

- - - 2011. The EU and Interregionalism: Patterns of Engagement. Aldershot: Farnham.

East Asia Economic Analytical Unit. 1994. ASEAN Free Trade Area: Trading Bloc or Building Bloc? Canberra: Australian Department of Foreign Affairs and Trade (DFAT).

Eichbaum, Chris, and Rolf Gerritsen. 1993. "The Impossible Politics of CER? The Prospects for the ANZ Closer Economic Relations Agreement in 1993 and Beyond." Australian Quarterly no. 65 (1):516-533. 
European Commission. 1994. Communication from the Commission to the Council: Towards a New Asia Strategy. Brussels: COM(4)314.

Fenton, Robert T. 1968. "New Zealand's Export Trade in Forest Products with Australia." New Zealand Journal of Forestry no. 13 (1):5-29.

FitzGerald, Stephen. 1997. Is Australia an Asian Country?: Can Australia Survive in an East Asian Future? St. Leonards, N.S.W.: Allen \& Unwin.

Gilson, Julie. 2001. "Europe-Asia: The Formal Politics of Mutual Definition." In The European Union and East Asia: Interregional Linkages in a Changing Global System, edited by Peter W. Preston and Julie Gilson. Cheltenham: Edward Elgar.

---. 2002. Asia Meets Europe: Inter-Regionalism and the Asia-Europe Meeting. Cheltenham: Edward Elgar.

Girard, Dominique. 2011. Interview by Author. Singapore, 4 August.

Goff, Phil. 2001. "The Trans-Tasman Relationship: A New Zealand Perspective." The Drawing Board no. 2 (1):1-9.

Gold, Hyam, and Ramesh Thakur. 1982. "New Zealand and Australia: Free Trade Agreement Mark II." The World Today no. 38 (10):402-410.

Guest, Morris, and John Singleton. 1999. "The Mururapa Project and Industrial Development in New Zealand 1945-65." Australian Economic History Review no. 39 (1):52-71. doi: 10.1111/14678446.00038 .

Gyngell, Allan. 2008. Ambition: The Emerging Foreign Policy of the Rudd Government. Sydney: Lowy Institute for International Policy.

Hall, Peter A., and Rosemary C. R. Taylor. 1996. "Political Science and the Three New Institutionalisms." MPIFG Discussion Paper no. 96 (6).

Hänggi, Heiner. 1999. "ASEM and the Construction of the New Triad." Journal of the Asia Pacific Economy no. 4 (1):56-80.

- - . 2000. Interregionalism: Empirical and Theoretical Perspectives. In Workshop on Dollars, Democracy and Trade: External Influence on Economic Integration in the Americas. Los Angeles, CA.

- - . 2002. Interregionalism in Comparative Perspective: In Search of a Typology. In Conference on Inter-Regionalism in International Politics. Freiburg.

Heenan, Peter. 2009. "New Zealand Engagement in East Asian Regional Security Architecture." MFAT Internal Report.

Henning, C. Randall. 2009. "The Future of the Chiang Mai Initiative: An Asian Monetary Fund." Peterson Institute for International Economics: Policy Brief (5).

Higgot, Richard, and Richard Stubbs. 1995. "Competing Conceptions of Economic Regionalism: APEC versus EAEC in the Asia Pacific." Review of International Political Economy no. 2 (3):516-535.

High Level Task Force. 2000a. The Angkor Agenda: Report of the High Level Task Force on the AFTACER Free Trade Area. http://www.dfat.gov.au/fta/aanzfta/angkor-agenda.pdf.

- - . 2000b. Press Statement of the Third Meeting of the High Level Task Force on the AFTA-CER Free Trade Area (AFTA-CER FTA), Siem Reap, Cambodia, 2-3 August. (December 1, 2011), http://www.asean.org/613.htm.

Hill, Christopher. 1994. "The Capability-Expectations Gap, or Conceptualizing Europe's International Role." In Economic and Political Integration in Europe: Internal Dynamics and Global Context, edited by Simon Bulmer and Andrew Scott, 103-126. Oxford: Blackwell.

Hollander, Robyn, and Haig Patapan. 2007. "Pragmatic Federalism: Australian Federalism from Hawke to Howard." Australian Journal of Public Administration no. 66 (3):280-297.

Hooghe, Liesbet, and Gary Marks. 2001. Multi-level Governance and European Integration. Oxford: Rowman and Littlefield Publishers.

Jetschke, Anja. 2010. Do Regional Organizations Travel? European Integration, Diffusion and the Case of ASEAN. In KFG Working Paper Series. Freie Universitat Berlin: Kolleg-Forschergruppe (KFG), "The Transformative Power of Europe". 
Joint Standing Committee on Foreign Affairs, Defence and Trade, 01/12/97. 1997. Relations with ASEAN. Senate Hansard: Joint Committees, http://parlinfo.aph.gov.au/.

Kawai, Masahiro. 2005. "East Asian Economic Regionalism: Progress and Challenges." Journal of Asian Economics no. 16 (1):29-55.

Keeling, Steve. 1996. "ACCSQ-CER Brunei Meeting." Fax to Graham Boxall (Ministry of Commerce). 4 March.

Krugman, Paul. 1991. "The Move Toward Free Trade Zones." Economic Review (November):5-25.

- - . 1993. "Regionalism versus Multilateralism: Analytical Notes." In New Dimensions in Regional Integration, edited by Jaime De Melo and Arvind Panagariya, 58-78. Cambridge: Cambridge University Press.

Kyodo News International Inc. 2000. "Malaysia Casts Shadow over AFTA-CER Merger Talks." Asian Economic News, 9 October.

Leslie, John, and Annmarie Elijah. 2011. A Comparator for the EU? Regional Integration, Sequencing and the Invisible Institutions of Closer Economic Relations between Australia and New Zealand. APSA 2011 Annual Meeting Paper, http://ssrn.com/paper=1900020.

Lloyd, Peter John. 1995. "The Future of Trans-Tasman Closer Economic Relations." Agenda no. 2 (3):267-280.

Marks, Gary, Liesbet Hooghe, and Kermit Blank. 1996. "European Integration from the 1980s: StateCentric v. Multi-level Governance." JCMS: Journal of Common Market Studies no. 34 (3):341378. doi: 10.1111/j.1468-5965.1996.tb00577.x.

Mattli, Walter. 1999. The Logic of Regional Integration: Europe and Beyond. Cambridge: Cambridge University Press.

Mattli, Walter, and Thomas Plümper. 2004. "The Internal Value of External Options: How the EU Shapes the Scope of Regulatory Reforms in Transition Countries." European Union Politics no. 5 (3):307-330.

McLean, Denis. 2003. The Prickly Pair: Making Nationalism in Australia and New Zealand. Dunedin: University of Otago Press.

Mein Smith, Philippa. 2007. "Did Muldoon Really 'Go Too Slowly' with CER?" New Zealand Journal of History no. 41 (2):161-179.

Meunier, Sophie, and Kalypso Nicolaïdis. 2006. "The European Union as a Conflicted Trade Power." Journal of European Public Policy no. 13 (6):906-925. doi: 10.1080/13501760600838623.

Ministry of Foreign Affairs. 1973a. Internal Telegram from Singapore to Wellington (No. 967). 26 November.

- - . 1973b. Internal Telegram from Singapore to Wellington (No. 1049). 26 December.

- - . 1973c. Internal Telegram from Wellington to Singapore (No. 1301). 24 December.

- - 1974a. Internal Telegram from Canberra to Singapore (No. 80); Wellington (No. 3072); and Kuala Lumpur (No. 79). 24 December.

-- - 1974b. Internal Telegram from Singapore to Wellington (No. 164). 14 February.

- - . 1974c. Internal Telegram from Singapore to Wellington (No. 788). 28 August.

-- . 1974d. "Meeting with G.E. Bogaars, Permanent Secretary, Foreign Affairs (Singapore)." Internal Ministry Report.

- - . 1975. "Report of ASEAN/New Zealand Meeting, Wellington, 15-16 July 1975." Internal Ministry Report.

- - . 1977a. "ASEAN/New Zealand Joint Trade Study Group." Internal Telegram from Canberra to Wellington (No. 302). 22 February.

- - . 1977b. "ASEAN/New Zealand Joint Trade Study Group." Internal Telegram from Wellington to Canberra (No. 348). 18 February.

- - . 1978. Confidential Internal Fax from Canberra to Wellington (No. 2222). 26 September.

-- - 2005. The Australia-New Zealand Closer Economic Relationship. Wellington: Printlink.

Ministry of Foreign Affairs and Trade. 1995. "AFTA/CER: Update." Internal MFAT Communication (File No. 104/434/14). n.d. 
-- - 1996. "AFTA/CER: SOM." Fax from Wellington to ASEAN posts (File 104/434/14). 7 June.

- - . 2009. New Zealand Membership of the Asia Europe Summit [sic]: Paper for the Minister of Foreign Affairs, 3 July 2009. Wellington.

Moravcsik, Andrew. 1991. "Negotiating the Single European Act: National Interests and Conventional Statecraft in the European Community." International Organization no. 45 (1):19-56. doi: $10.1017 /$ S0020818300001387.

- - . 1993. "Preferences and Power in the European Community: A Liberal Intergovernmentalist Approach." JCMS: Journal of Common Market Studies no. 31 (4):473-524. doi: 10.1111/j.1468-5965.1993.tb00477.x.

-- - 1998. The Choice for Europe: Social Purpose and State Power from Messina to Maastricht. Ithaca: Cornell University Press.

Mugliston, Michael. 2009. Negotiating the ASEAN-Australia-New Zealand Free Trade Agreement. In Intergovernmental Relations 2009 Conference - A Practical Approach in a Changing Landscape. Canberra.

- - - 2011. Telephone Interview by Author. Wellington, 15 December.

Murray, Philomena. 2010. "Australia in ASEM: Engagement and Expectations." In The Asia-Europe Meeting: Engagement, Enlargement and Expectations, edited by Lay Hwee Yeo and Wilhelm Hofmeister, 52-78. Singapore: EU Centre and Konrad Adenauer Stiftung.

New Zealand Government. 2010. "McCully to Attend ASEM Summit in Brussels." Press Release: New Zealand Government, 4 October.

New Zealand Ministry Official. 2011. Interview by Author. Wellington, 17 November.

New Zealand Official. 2011. Telephone Interview by Author. Wellington, 9 December.

North, Douglass C. 1990a. "Institutions and a Transaction-Cost Theory of Exchange." In Perspectives on Positive Political Economy, edited by James E. Alt and Kenneth A. Shepsle, 182-194. Cambridge: Cambridge University Press.

- - - 1990b. Institutions, Institutional Change, and Economic Performance. Cambridge: Cambridge University Press.

- - - 1992. "Transaction Costs, Institutions and Economic Performance." International Center for Economic Growth: Occasional Papers (30):1-32.

Nuttal, Simon. 1990. "The Commission: Protagonists of Inter-Regional Cooperation." In Europe's Global Links: The European Community and Inter-Regional Cooperation, edited by Geoffrey Edwards and Elfriede Regelsberger, 143-160. London: Pinter Publishers.

Ohmae, Kenichi. 1985. Triad Power: The Coming Shape of Global Competition. London: Collier Macmillan.

Okamoto, Jiro. 2010. Australia's Foreign Economic Policy and ASEAN. Singapore: ISEAS Publishing.

Painter, Martin. 1998. Collaborative Federalism: Economic Reform in Australia in the 1990s. Cambridge: Cambridge University Press.

- - . 2001. "Multi-level Governance and the Emergence of Collaborative Federal Institutions in Australia." The Policy Press no. 29 (2):137-50.

Patman, Robert G. 2001. "Globalisation and Trans-Tasman Relations: Integration or Divergence?" Australian Journal of International Affairs no. 55 (3):389-402.

Power, Simon. 2009. Remaking the Trans-Tasman World. Speech to the New Zealand Institute of International Affairs, 13 October http://www.beehive.govt.nz/speech/remaking-transtasman-world.

Ravenhill, John. 1998. "Adjusting to the ASEAN Way: Thirty Years of Australia's Relations with ASEAN." The Pacific Review no. 11 (2):267-289. doi: 10.1080/09512749808719257.

Regelsberger, Elfriede. 1990. "The Dialogue of the EC/Twelve with Other Regional Groups: A New European Identity in the International System?" In Europe's Global Links: The European Community and Inter-Regional Cooperation, edited by Geoffrey Edwards and Elfriede Regelsberger, 3-26. New York: St. Martin's Press. 
Richardson, Michael. 2005. "Australia-Southeast Asia Relations and the East Asian Summit." Australian Journal of International Affairs no. 59 (3):351-365. doi: 10.1080/10357710500231149.

Roloff, Ralf. 2001. Europa, Amerika und Asien zwischen Globalisierung und Regionalisierung. Das Interregionale Konzert und die okonomische Dimension internationaler Politik. Paderborn: Schoeningh.

Rosamond, Ben. 2000. "Regional Indentities and Inter-Regional Dialogue: The European Union and the ASEM Process." Global Economic Review no. 29 (1):79-96. doi: $10.1080 / 12265080008449783$.

Rudd, Kevin. 2008. Toward an Asia-Pacific Union, Address to the Asia Society AustralAsia Centre, 4 June, 2008. Sydney.

Rüland, Jürgen. 2010. "Balancers, Multilateral Utilities or Regional Identity Builders? International Relations and the Study of Interregionalism." Journal of European Public Policy no. 17 (8):1271-1283. doi: 10.1080/13501763.2010.513586.

Schiff, Maurice, and L. Alan Winters. 2003. Regional Integration and Development. Washington: The World Bank.

Schimmelfennig, Frank. 2004. "Liberal Intergovernmentalism." In European Integration Theory, edited by Antje Wiener and Thomas Diez, 75-96. Oxford: Oxford University Press.

Schmitter, Philippe C. 2004. "Neo-Neofunctionalism." In European Integration Theory, edited by Antje Wiener and Thomas Diez, 45-74. Oxford: Oxford University Press.

Scollay, Robert, Christopher Findlay, and Uwe Kaufmann. 2011. Australia New Zealand Closer Economic Relations Trade Agreement (ANZCERTA) and Regional Integration. Singapore: ISEAS Publishing.

Severino, Rodolfo C. 2006. Southeast Asia in Search of an ASEAN Community: Insights from the Former ASEAN Secretary-General. Singapore: ISEAS Publishing.

---. 2011. Foreword: Australia New Zealand Closer Economic Relations Trade Agreement (ANZCERTA) and Regional Integration. Singapore: ISEAS Publishing.

Sjöstedt, Gunnar. 1977. The External Role of the European Community. Westmead: Gower.

Söderbaum, Fredrik, and Luk Van Langenhove. 2005. "Introduction: the EU as a Global Actor and the Role of Interregionalism." Journal of European Integration no. 27 (3):249-62.

Statistics New Zealand. 1996. Overseas Trade Statistics: 1995. Wellington: Statistics New Zealand.

- - . 2001. Key Statistics September 2001. Wellington: Statistics New Zealand.

Taylor, David. 2011. Telephone Interview by Author. Wellington, 7 October.

Teo, Eric Chu Cheow. 2006. The IMF/WB Meeting in Singapore: Asia and Europe's Role in the World Economy. RSIS Commentaries 97/2006, http://dr.ntu.edu.sg/handle/10220/4224.

Wiener, Antje, and Thomas Diez. 2004. European Integration Theory. Oxford: Oxford University Press. Woodfield, Ted. 2008. Against the Odds: Negotiating for New Zealand's Future. Wellington: Dunmore Publishing.

World Trade Organization. 1996. "New Zealand." Trade Policy Reviews (October). 